$\operatorname{Dan} z$

\title{
DIGITAL MODELS OF A GLACIAL OUTWASH AQUIFER IN THE PEARL-SALLIE LAKES AREA, WEST-CENTRAL MINNESOTA
}

U. S. GEOLOGICAL SURVEY

Water-Resources Investigations 40-75

Prepared in cooperation with the U. S. Environmental Protection Agency

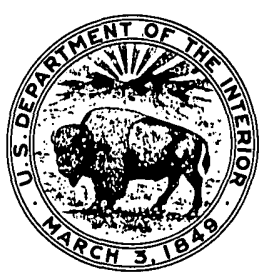




\begin{tabular}{|c|c|c|}
\hline $\begin{array}{l}\text { BIBLIOGRAPHIC DATA } \\
\text { SHEET }\end{array}$ & 1. Report No. & 3. Recipient's Accession No. \\
\hline \multirow{2}{*}{\multicolumn{2}{|c|}{$\begin{array}{l}\text { 4. Title and Subtitle } \\
\text { DIGITAL MODELS OF A GLACIAL OUTWASH AQUIFER IN THE PEARL-SALLIE } \\
\text { LAKES AREA, WEST-CENTRAL MINNESOTA }\end{array}$}} & $\begin{array}{l}\text { 5. Report Date } \\
\text { November } 1975\end{array}$ \\
\hline & & 6. \\
\hline \multicolumn{2}{|c|}{$\begin{array}{l}\text { 7. Author(s) } \\
\text { Steven P. Larson, Mark S. McBride, and Ronald J. Wolf }\end{array}$} & $\begin{array}{l}\text { 8. Performing Organization Rept. } \\
\text { No. USGS/WRI 40-75 }\end{array}$ \\
\hline \multirow{2}{*}{\multicolumn{2}{|c|}{$\begin{array}{l}\text { 9. Performing Organization Name and Address } \\
\text { U.S. Geological Survey } \\
\text { Water Resources Division } \\
\text { Room } 1033 \text { Post Office Building } \\
\text { St. Paul, Minnesota } 55101\end{array}$}} & 10. Project/Task/Work Unit No. \\
\hline & & 11. Contract/Grant No. \\
\hline \multirow{2}{*}{\multicolumn{2}{|c|}{$\begin{array}{l}\text { 12. Sponsoring Organization Name and Address } \\
\text { U.S. Geological Survey } \\
\text { Water Resources Division } \\
\text { Room 1033 Post Office Building } \\
\text { St. Paul, Minnesota 55101 }\end{array}$}} & $\begin{array}{l}\text { 13. Type of Report \& Period } \\
\text { Covered } \\
\text { Final }\end{array}$ \\
\hline & & 14. \\
\hline
\end{tabular}

15. Supplementary Notes

Prepared in cooperation with the U.S. Environmental Protection Agency

16. Abstracts The need for study of lake-ground-water interchange has been accentuated by eutrophication of lakes in the Pearl-Sallie Lakes area of west-central Minnesota. The local ground-water flow system is dominated by an outwash aquifer that is sandwiched between two till layers in the western part of the area and exposed at the land surface in the eastern part. Ground water discharges from the aquifer into lakes in the outwash area but is recharged from lakes in the till-covered area. Irregular aquifer geometry resulted in a complex ground-water flow system. Simulation of the system by areal and vertical-section models showed that the lakes significantly control groundwater flow near their boundaries. Inadequate field data and complex geology caused difficulty in obtaining solutions with the vertical-section model. The models may be used to guide collection and interpretation of field data, and quantification of the ground-water flow system. With modification, they could be used to predict aquifer response to transient stresses. They also could be incorporated into more complex models to determine the movement of solutes in the ground-water system.

17. Key Words and Document Analysis. 17a. Descriptors

*Hydrogeology, *Ground-water movement, *Mathematical models, *Lakes, Surface-groundwater relationships, Water levels, Water-level fluctuations, Computer models, Cross sections, Seepage, Aquifer characteristics, Leakage.

17b. Identifiers Open-Ended Terms

Pelican River basin, Alexandria Moraine

17c. COSATI Field/Group

\begin{tabular}{|c|c|c|}
\hline 18. Availability Statement & $\begin{array}{l}\text { 19. Security Class (This } \\
\text { Report) } \\
\text { UNCLASSIEJED }\end{array}$ & $\begin{array}{c}\text { 21. No. of Pages } \\
39\end{array}$ \\
\hline Release unlimited & $\begin{array}{l}\text { 20. Security Class (This } \\
\text { Page } \\
\text { UNCLASSIFIED }\end{array}$ & 22. Price \\
\hline
\end{tabular}


DIGITAL MODELS OF A GLACIAL OUTWASH

AQUIFER IN THE PEARL-SALLIE LAKES AREA,

WEST-CENTRAL MINNESOTA

By Steven P. Larson, Mark S. McBride, and Ronald J. Wolf

U.S. GEOLOGICAL SURVEY

Water-Resources Investigations 40-75

Prepared in cooperation with the

U.S. Environmental Protection Agency

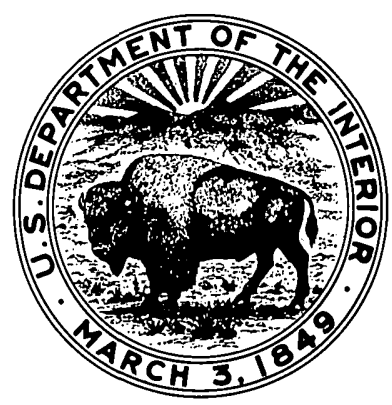

November 1975 


\section{UNITED STATES DEPARTMENT OF THE INTERIOR \\ Thomas S. Kleppe, Secretary \\ GEOLOGICAL SURVEY \\ V. E. McKelvey, Director}

For additional information write to:

U.S. Geological Survey 1033 Post Office Building

St. Paul, Minnesota 55101 
Abstract ........................... . I

Introduction . . . . . . . . . . . . . . . . . . . . 1

Background ... . . . . . . . . . . . . . . 1

Purpose and scope . . . . . . . . . . . . . . . 2

Acknowledgments . . . . . . . . . . . . . . . . 3

Description of study area... . . . . . . . . . . . 3

Methods of investigation . . . . . . . . . . . . 3

Geohydrology . . . . . . . . . . . . . . . . 5

Geology .. . . . . . . . . . . . . . . . 5

Hydrology . . . . . . . . . . . . . . . . . . 7

Digital models . . . . . . . . . . . . . . . . . . . 8

Areal two-dimensional model . . . . . . . . . . 8

Model inputs... . . . . . . . . . . . . 10

Pearl-Sallie area digital model . . . . . . . . 10

Lake-ground-water interaction . . . . . . . 12

Results . . . . . . . . . . . . . . 18

Summary and discussion of areal two-dimensional model. . 26

Vertical-section model . . . . . . . . . . . . 27

Model inputs . . . . . . . . . . . . . . 28

Model output . . . . . . . . . . . . . . . . . 29

Application of the vertical-section model . . . . . 29

Results ................... 31

Shortcomings and difficulties . . . . . . . 32

Summary and discussion of vertical cross-section model . 35

Summary and conclusions . . . . . . . . . . . . . . 36

References . . . . . . . . . . . . . . . . . . 38

\section{ILLUSTRATIONS}

Figure 1. Map showing surficial geology and geohydrologic

Page

section.................... . 4

2. Map showing data-collection sites . . . . . . . . 6

3. Hydrographs showing water-level fluctuations caused

by gravel-washing operations . . . . . . . . . . 9

4. Grid configuration for areal model . . . . . . . . . 11

5. Map showing configuration of the till surface under-

lying outwash aquifer . . . . . . . . . . . . 13

6. Map showing hydraulic conductivity of outwash aquifer . 14

7. Map showing configuration of the bottom of upper till . 15

8. Map showing thickness of upper till . . . . . . . . 16

9. Map showing configuration of water table in upper till. 17

10. Map showing potentiometric surface in outwash aquifer and line of vertical-section model . . . . . . 19 
Figure 11. Map showing steady-state potentiometric surface computed by areal digital model . . . . . . . 20

12. Map showing computed saturated thickness of outwash aquifer . . . . . . . . . . . . . . 21

13. Map showing computed transmissivity of outwash aquifer . . . . . . . . . . . . . . . 22

14. Hydrogeology and vertical-section model results . . 30

15. Graph of horizontal flow rate versus distance from shore as predicted by model . . . . . . . . 33

\section{TABLES}

Page

Table 1. Values of hydraulic conductivity estimated from field data and used in vertical-section model . . . . . . 31 


\title{
DIGITAL MODELS OF A GLACIAL OUTWASH AQUIFER IN THE \\ PEARL-SALLIE LAKES AREA, WEST-CENTRAL MINNESOTA
}

By Steven P. Larson, Mark S. McBride, and Ronald J. Wolf

\begin{abstract}
The need for study of lake-ground-water interchange has been accentuated by eutrophication of lakes in the Pearl-Sallie Lakes area of west-central Minnesota. The local ground-water flow system is dominated by a sand and gravel outwash aquifer that is sandwiched between two layers of till in the western part of the area and exposed at the land surface in the eastern part. Water discharges from the aquifer into lakes in the outwash area but the aquifer is recharged from lakes in the till-covered area. Irregular aquifer geometry has resulted in a complex ground-water flow system.

Simulation of the system by areal and vertical-section models has shown that the lakes significantly control ground-water flow near their shores. Inadequate field data and complex geology caused severe difficulty in obtaining solutions with the vertical-section model. Evaluation of the models has indicated that they may be used to guide field-data collection, interpretation of data, and quantification of the ground-water flow system. With modification, the models could be used to predict aquifer response to transient stresses. Also, they could be incorporated into more complex models, to determine the movement of solutes in the ground-water system.
\end{abstract}

\section{INTRODUCTION}

\section{Background}

All lakes go through a natural process of change and aging known as eutrophication. This process is characterized by accumulation of plant nutrients, decreased depth, and increased temperature. This leads to increased fertility and proliferation of algae and, in later stages of the lake's natural life cycle, weed growth, swampiness, and eventual disappearance as an open body of water. Excessive influx of manmade nutrients accelerates the normal aging process so that algal blooms and other vegetation problems interfere with recreational use of the lakes. Eutrophication of many lakes has accelerated since early in the century, especially in the last 20 years. Rapid eutrophication makes it necessary to establish standards for operation of sewagedisposal facilities whose effluent is discharged into lakes. It is 
difficult, however, to set meaningful standards if the hydrologic system in the vicinity of lake basins is not understood. Present literature contains few studies dealing with lake-ground-water relationships. Consequently, the U.S. Environmental Protection Agency funded the U.S. Geological Survey in a study of lake-ground-water interchange in an area where accelerated eutrophication has occurred. Study results will be used to guide further studies and interpretations of the effects of lake-ground-water interaction on water quality.

For use of those readers who may prefer metric units rather than English units, the conversion factors for the terms used in this report are listed below.

Multiply English unit

inches (in)

feet ( $\mathrm{ft}$ )

miles ( $\mathrm{mi}$ )

square miles $\left(\mathrm{mi}^{2}\right)$

feet per second ( $\mathrm{ft} / \mathrm{s}$ )

cubic feet per second $\left(\mathrm{ft}^{3} / \mathrm{s}\right)$

feet per day ( $f t / d$ )

acre-feet per year

(acre-ft/yr)

feet per mile ( $\mathrm{ft} / \mathrm{mi}$ )
By To obtain metric unit

25.4

0.3048 metres $(\mathrm{m})$

1.609 kilometres $(\mathrm{km})$

2.590 square kilometres $\left(\mathrm{km}^{2}\right)$

0.3048 metres per second $(\mathrm{m} / \mathrm{s})$

0.02832 cubic metres per second $\left(\mathrm{m}^{3} / \mathrm{s}\right)$

0.3048 metres per day $(\mathrm{m} / \mathrm{d})$

$1.233 \times 10^{3}$ cubic metres per year $\left(\mathrm{m}^{3} / \mathrm{yr}\right)$

0.1894 metres per kilometre $(\mathrm{m} / \mathrm{km})$

\section{$\underline{\text { Purpose and scope }}$}

The purpose of this investigation is to 1) study the hydrologic system in a glaciated terrain typified by numerous lakes, with particular focus on the effects of lake-ground-water interchange, 2) simulate the natural system by using two digital modeling methods--areal (map view) and vertical section, and 3 ) evaluate the utility of the models and determine the kinds and amount of basic data needed to obtain reasonable simulations.

The major study objective is to learn how best to analyze lakeground-water interchange with a goal toward developing tools for coping with the eutrophication problem. Primarily, this report evaluates difficulties met in model simulation of the natural system and the sensitivity of model results to changes of different parameters in the system.

The models, as developed, were used only to show how well this particular hydrologic system could be simulated, given the amount and kinds of data collected. The next step would be to develop additional equations describing solute transport in porous media and to reprogram the models so they can be used to predict movement of chemical concentrates in the subsurface. This step would provide additional insight into the lake eutrophication problem. 


\section{Acknowledgments}

The authors thank the many residents and land owners who provided assistance, information, and access to their property for auger test drilling. Notably, Mr. Albert McDonough, Mr. Earl L. McDowell, Sr., $\mathrm{Mr}$. Albert M. Ungerecht, and the Detroit Lakes Country Club permitted access to their land for conducting pumping tests. Also, well records, information and suggestions given by well drillers, Mr. Eugene Hosmer and $\mathrm{Mr}$. Joseph Johnson, are greatly appreciated.

\section{Description of study area}

The area selected for study and modeling, about $9 \mathrm{mi}^{2}\left(23 \mathrm{~km}^{2}\right)$, is in T.138 N., R.41 W. (Lake View Township), and T.138 N., R.42 W. (Lake Eunice Township), Becker County, in west-central Minnesota (fig. 1). It is about $3 \mathrm{mi}(5 \mathrm{~km})$ southwest of the city of Detroit Lakes in a region well known for fishing, boating, and skiing.

Summers are short and mild; winters are long and severe. The average annual temperature is $39.20 \mathrm{~F}\left(4.0^{\circ} \mathrm{C}\right)$; monthly averages range from $50 \mathrm{~F}\left(-15^{\circ} \mathrm{C}\right)$ in January to $69.5^{\circ} \mathrm{F}\left(20.8^{\circ} \mathrm{C}\right)$ in July. Annual normal precipitation is 23.57 in $(599 \mathrm{~mm})$, ranging from 0.65 in (165 mm) in February to 3.95 in $(100 \mathrm{~mm})$ in both June and August. A large part of the precipitation, 68.8 percent, falls between May and September.

Physiographically, the area is in the Western Lake section of the Central Lowland Province (Fenneman, 1938), lying within a broad belt of hilly lake country trending north-south through west-central Minnesota. The area is a small segment of the valley of the Pelican River, which flows southward, connecting many large lakes before joining the Otter Tail River. The part of the Pelican River basin studied includes Sallie, Pearl, Dart, Little Pearl, Monson, Fox, and Mud Lakes, together with many small unnamed lakes, potholes, and marshes. Most of these lakes and wetlands are in steep sided closed depressions. Total relief within the study area is about $110 \mathrm{ft}(33.5 \mathrm{~m})$, with altitudes ranging from about 1,330 ft $(405 \mathrm{~m})$ at Lake Sallie to above 1,440 $\mathrm{ft}(439 \mathrm{~m})$ on the highest hills.

\section{Methods of investigation}

Evaluation of the hydrogeology involves definition of the spatial and temporal distribution of the following parameters: aquifer geometry (thickness and areal extent), aquifer hydraulic characteristics (storage coefficient and hydraulic conductivity), and external factors affecting the aquifer system (lake levels and aquifer discharge and recharge). Geologic information was collected at 100 sites using a power auger. Observation wells'were installed at 52 sites and were monitored periodically for water-level fluctuations. Surface-water staff gages were monitored at seven locations concurrently with the observation wells. 


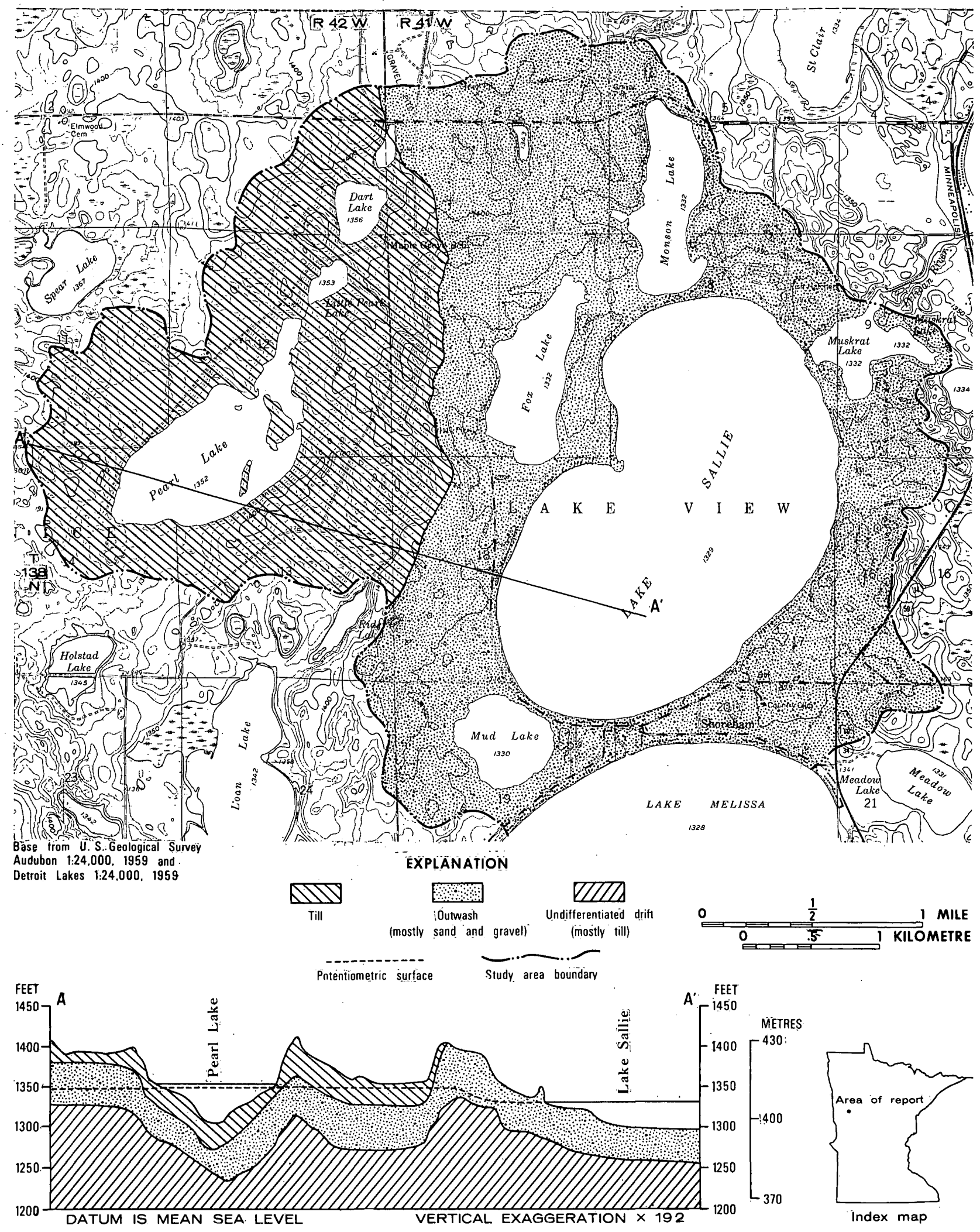

Figure 1.--Generalized surficial geology and geohydrologic section. 
Additional data were collected from two aquifer tests, lake cores in Dart and Pearl Lakes, and grain-size analyses on 32 samples gathered during test drilling. Previous studies of Lake Sallie and other nearby areas were reviewed and pertinent data were extracted. The locations of test holes, observation wells, lake-core sites, and aquifer tests are shown in figure 2 .

An areal two-dimensional model and a vertical cross-section model were developed after analysis and interpretation of the basic data. The models were evaluated primarily as to their 1) interpretive and calculative utilities with respect to hydrogeologic studies and 2) required quantity and quality of input data.

\section{GEOHYDROLOGY}

$\underline{\text { Geology }}$

Bedrock, deeply buried throughout the study area, consists of Precambrian metamorphic rocks, in places mantled by thin patches of Cretaceous shale and sandstone. The bedrock surface is at an altitude of about $870 \mathrm{ft}(265 \mathrm{~m})$ and slopes regionally to the northwest at about $10 \mathrm{ft} / \mathrm{mi}(1.9 \mathrm{~m} / \mathrm{km}$ ) (Winter and others, 1969). About $500 \mathrm{ft}(152 \mathrm{~m})$ of Pleistocene glacial deposits cover the bedrock surface.

The area is within the Alexandria moraine complex (Wright and Ruhe, 1965) of Wisconsin age. Although pre-Wisconsin Drift has not been recognized at the surface, the area is well within the limits of the older Nebraskan, Kansan, and Illinoian Drift sheets, deposits of which probably occur beneath the younger drift. Near-surface deposits consist of older Wadena lobe drift buried by younger Des Moines lobe drift. The following units, listed from oldest to youngest, have been distinguished:

1. Yellow sand and clay, probably of pre-Wisconsin age.

2. Sandy gray silty-clayey till of the Wadena lobe.

3. Gray silty-clayey till of the Des Moines lobe.

4. Sand and gravel outwash derived from melting of the Des Moines lobe.

5. Surficial gray silty-clayey till, buff where oxidized, laid down by the readvancement of the Des Moines lobe.

The last three units constitute the geologic framework controlling the flow pattern of the aquifer-lake system. The outwash aquifer (unit 4) in which many of the lakes occur, ranges from 0 to as much as $100 \mathrm{ft}(30 \mathrm{~m})$ in thickness and is sandwiched between two layers of till (units 5 and 3 ) in the western part of the area (fig. 1). The depressions which form the lakes in the eastern part (outwash area), as well as in the western part (till area), were formed by ice blocks which melted long after retreat of the glacial ice lobes. 


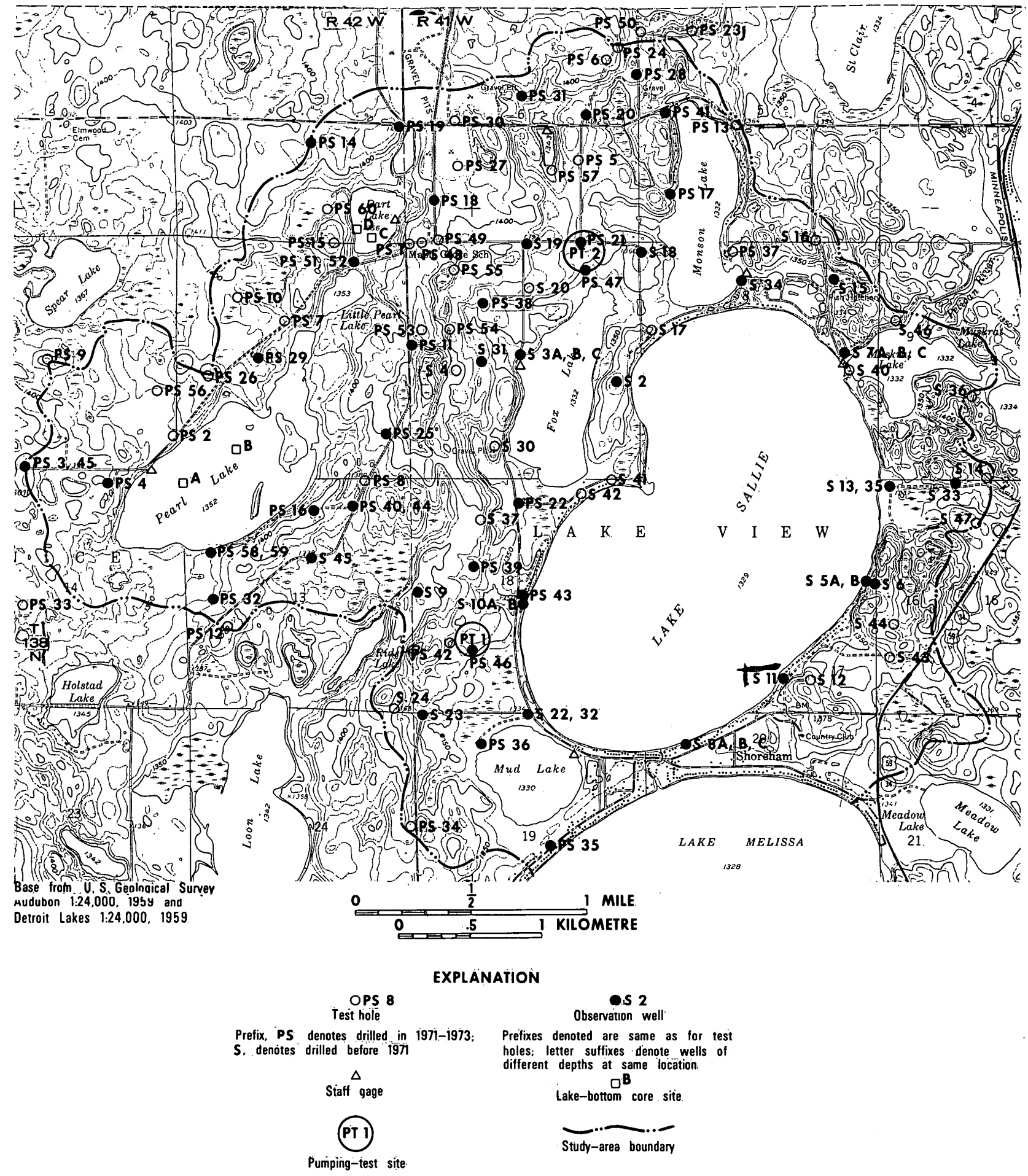

Figure 2.--Location of data collection sites. 


\section{Hydrology}

The hydrology of the Otter Tail River watershed was described by Winter and others (1969). Regionally, ground water within the drift flows from a north-south trending ground-water divide east of Lake Sallie. The water moves westward, passes beneath the Pearl-Sallie Lake area, and discharges in a lake-plain region about $25 \mathrm{mi}(40 \mathrm{~km})$ west of the study area near the Red River of the North. Many locally significant ground-water flow systems, such as that in the outwash aquifer in the study area, are superimposed upon the regional system.

The map and cross section of figure 1 illustrate the general hydrologic situation in the study area. An outwash deposit of sand and gravel constitutes the main aquifer. In the eastern part of the study area (referred to subsequently as the outwash area) the aquifer is unconfined, and in direct connection with the lakes. To the west, the outwash is overlain by a layer of semi-permeable till, so that the aquifer is semi-confined, and is separated from the lakes by the till layer.

Based largely on pumping test data, hydraulic conductivity of the outwash aquifer was determined to be as high as $3.09 \times 10^{-3} \mathrm{ft} / \mathrm{s}\left(9.4 \times 10^{-4}\right.$ $\mathrm{m} / \mathrm{s}$ ). In contrast, the hydraulic conductivity of a sample of till taken from the bottom of Pearl Lake was determined by laboratory analys is to be $1.25 \times 10^{-9} \mathrm{ft} / \mathrm{s}\left(3.8 \times 10^{-10} \mathrm{~m} / \mathrm{s}\right)$. Thus, water moves much more readily in the outwash than in the till.

Between 3 and 6 in ( 76 and $152 \mathrm{~mm}$ ) of water per year is estimated to infiltrate into the surficial outwash (Reeder, 1972) and move to local discharge areas, such as lakes, streams, and marshes. Discharge into Lake Sallie from the surficial outwash was determined to be 2,657 and 3,059 acre-ft/yr $\left(3.15 \times 10^{6} \mathrm{~m}^{3} / \mathrm{yr}\right.$ and $\left.3.77 \times 10^{6} \mathrm{~m}^{3} / \mathrm{yr}\right)$ for water years 1969 and 1970, respectively (Mann and McBride, 1972).

In the western part of the area, recharge to the aquifer is impeded by the surficial till. The lakes here are continuous with the saturated zone within the till. Infiltrating water and water from the lakes seep downward through the till and into the underlying outwash aquifer, then move generally horizontally to places of discharge.

A buried till ridge underlies the outwash aquifer to the west of Lake Sallie. The ridge trends north-south, paralleling the easternmost limit of the surficial till (fig. 1), and may have been formed by compressional forces of the ice sheet that deposited the till. The ridge causes an elongate zone where the saturated section is thin in part of the overlying aquifer, as depicted in the hydrogeologic cross section show in figure 1 . The resulting effect on the potentiometric surface in the aquifer is a steepening of the hydraulic gradient in the immediate vicinity of the ridge (fig. 10). Effects of the ridge on model analyses are discussed later in this report. 
In addition to natural phenomena, waste water from a gravel-washing plant north of Dart Lake significantly affects the surficial-aquifer system. The washing plant uses an average of 698 acre-ft/yr $\left(8.59 \times 10^{5}\right.$ $\mathrm{m}^{3} / \mathrm{yr}$ ) of water, some of which infiltrates into the surficial aquifer and causes water-table fluctuations of as much as $14 \mathrm{ft}(4.3 \mathrm{~m})$ near the place of recharge. Most of the water is obtained from Dart Lake and supplemented by pumping from a buried glacial aquifer. The effect of this localized recharge was detected in observation wells in a large part of the study area, causing difficulty in the determination of steady-state flow conditions. Water use by the plant for 1972 and 1973 and hydrographs showing response of nearby observation wells to the recharge are shown in figure 3.

\section{DIGITAL MODELS}

\section{Areal two-dimensional model}

The areal two-dimensional model was patterned after a model developed by Pinder (1970). The model is used to determine an approximate solution to the partial differential equation of ground-water flow in two dimensions as given below (after Pinder and Bredehoeft, 1968, p. 1072).

$$
\frac{\partial}{\partial x}\left(T_{x x} \frac{\partial h}{\partial x}\right)+\frac{\partial}{\partial y}\left(T_{y y} \frac{\partial h}{\partial y}\right)=W(x, y)
$$

where

$\mathrm{T}_{\mathrm{xx}}$ and $\mathrm{T}_{\mathrm{Xy}}$ are principal components of the transmissivity tensor

$\mathrm{h}$ is the hydraulic head ( $L$ ), and

$\mathrm{W}$ is the volume flux per unit area $(\mathrm{L} / \mathrm{T})$.

Equation 1 assumes steady flow of a fluid in nonhomogeneous porous medium and that the principal axes of the transmissivity tensor are alined with the coordinate axes. A form of the finite-difference equation used to approximate equation 1 is given by Pinder (1970, p. 1). The iterative alternating-direction implicit technique (IADI) is used to solve a set of simultaneous equations developed by applying the finite-difference equation at a finite number of grid points. At each grid point, or node, aquifer properties and characteristics are specified. The matrix of nodes represents the size and characteristics of the real aquifer, and the solution of the simultaneous equations results in an areal distribution of hydraulic head in the aquifer. 


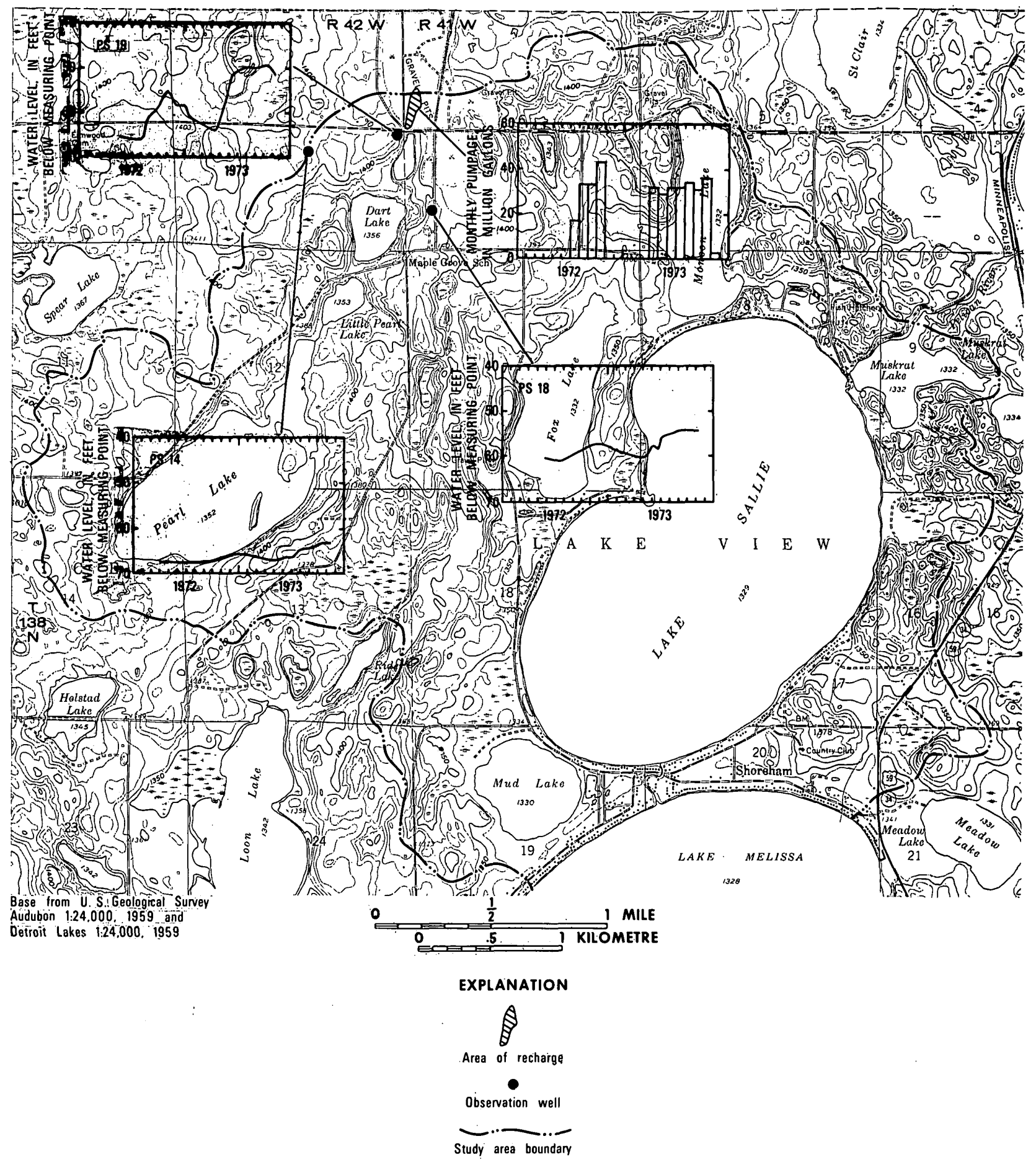

Figure 3.--Selected hydrographs showing water-level fluctuations caused by gravel-washing operations north of Dart Lake. 
Model inputs

At each node, the following aquifer properties and characteristics are specified.

1. Hydraulic conductivity, (L/T)

2. Aquifer base altitude, (L)

3. Thickness and hydraulic conductivity of a confining layer above aquifer, if present, $(\mathrm{L}, \mathrm{L} / \mathrm{T})$

4. Hydraulic head above the confining layer, (L)

5. Altitude of the bottom of the confining layer, ( $L$ )

6. Lateral and longitudinal dimensions of the area represented by each node, ( $L$ )

The steady nature of the model precludes consideration of the storage properties of the aquifer. Nonsteady flow problems would require inclusion of the storage coefficient and (or) specific yield and reprogramming of the model.

Hydrologic characteristics along the aquifer boundaries are specified by selecting one of three boundary conditions.

1. No flow across the boundary

2. Constant flux across the boundary

3. Constant hydraulic head at the boundary

In addition to aquifer properties and boundary conditions, any sources or sinks are included. Constant recharge to the aquifer is the only source whose value is specified. Leakage to or from the aquifer through the confining layer is determined as a part of the solution and, therefore, is not explicitly specified.

Pearl-Sallie area digital model

A 2,624 node $(64 \times 41)$ grid was selected to model the sand and gravel aquifer in the Pearl-Sallie Lake area (fig. 4). Each node represented an area $250 \mathrm{ft}(76 \mathrm{~m})$, east-west, by $500 \mathrm{ft}(152 \mathrm{~m})$, north-south. Nodes were elongated in this manner because of predominant north-south orientation of features in the aquifer. Thus, greater detail was available for describing east-west characteristics. The number of nodes was determined by weighing computer storage and computation time requirements against the amount of detail required to describe the aquifer geometry adequately.

The aquifer was modeled as unconfined in the eastern part of the study area--that is, in the area occupied by unconfined outwash (fig. 1) --and as confined in the western part of the study area. 

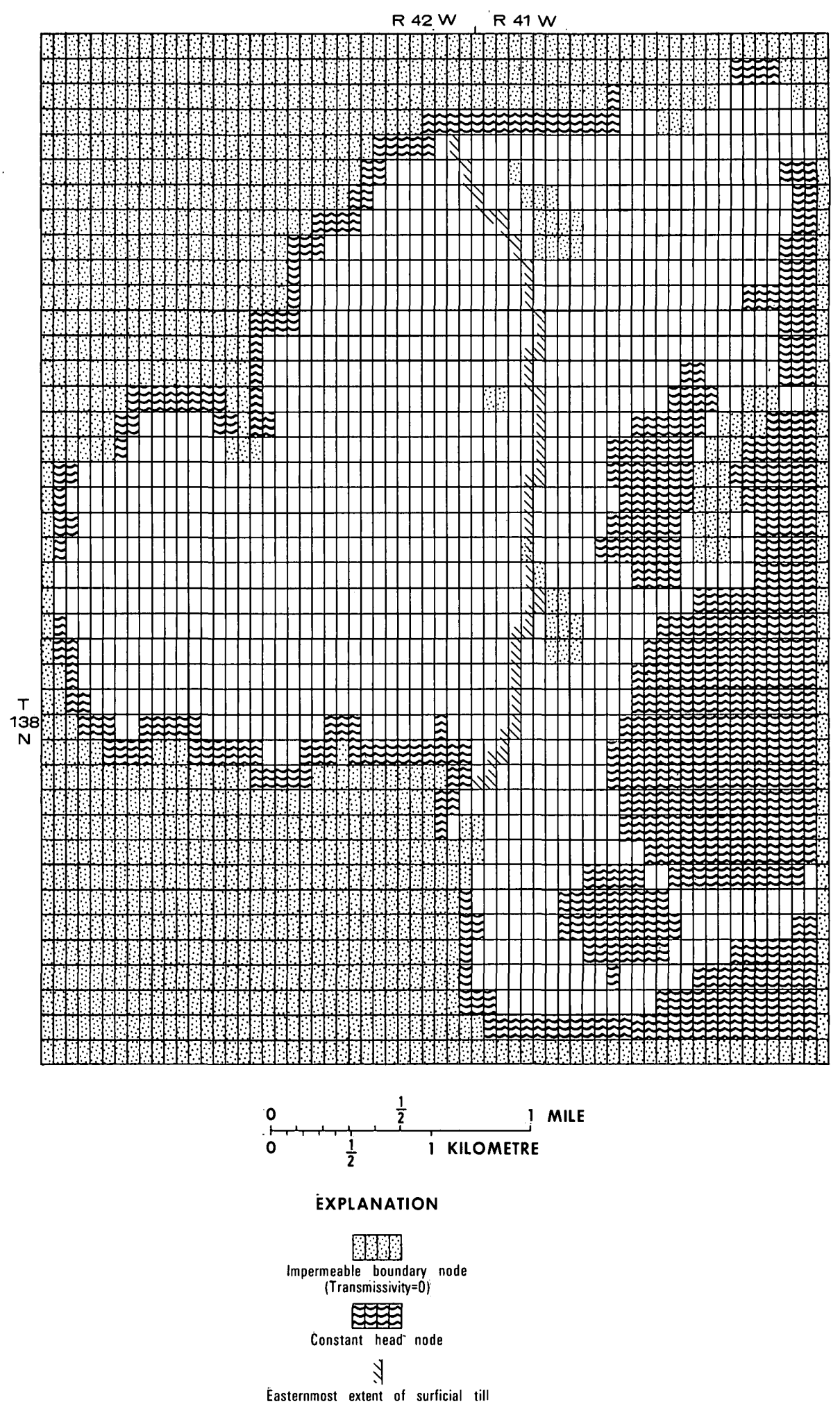

Figure 4.--Grid configuration for areal model. 
The following contour maps were used to determine parameter nodal values: 1) aquifer-base altitude, 2) aquifer hydraulic conductivity, 3 ) altitude of base of upper confining layer (in places where the aquifer is overlain by till), 4) thickness of confining layer (saturated part of overlying till, and 5) hydraulic head above the confining layer (water table within overlying till and certain lake levels). The maps are shown in figures 5 through 9, respectively.

Boundary conditions for nodes at the edge of the study area were assigned as 1) constant head, if the aquifer continued beyond the study area, or 2) no flow, if it did not continue. In addition, nodes within areas of known unsaturated conditions were treated as no-flow boundaries.

The boundary conditions are depicted in figure 4. Along the study area boundary a definite hydrologic boundary condition could not be established except where the aquifer was unsaturated. Recall that the unsaturated nodes were considered impermeable (no flow). The remaining nodes were assigned as constant head, and flow into or out of the aquifer through these boundary nodes (underflow) was determined as part of the solution.

Lake-ground-water interaction

The effect of lakes on the ground-water system was simulated by one of two methods. If evidence indicated poor hydraulic connection between a lake and the aquifer, that is, intervening material of low hydraulic conductivity, the lake level was modeled as the hydraulic head above a confining layer. Values of thickness and hydraulic conductivity were assigned to the confining layer to reflect the degree of hydraulic connection. Thus, a difference between lake level and head in the aquifer would result in recharge to (or discharge from) the aquifer. This approach was used for lakes within the area where the aquifer was overlain by till ( $f i g .1$ ). It was determined that these lakes reflected the water table in the till layer and that water was moving vertically from or through the till into the underlying aquifer.

Lakes in the remainder of the area (outwash area, fig. 1) were assumed to control the head in the aquifer at the lake-ground-water interface; therefore, interfaces were modeled as constant-head boundaries. This assumption was made because the lake levels are controlled largely by streams. The assumption was later checked by modeling a confining layer between the lakes and the aquifer and by removing the constant head boundaries at the interfaces. Under these conditions, reasonable results were obtained only where values for thickness and hydraulic conductivity were limited to $0.01 \mathrm{ft}\left(3 \times 10^{-3} \mathrm{~m}\right)$ and $2.3 \times 10^{-8}$ ft $\left(7 \times 10^{-9} \mathrm{~m}\right)$ per second, respectively, making the effects of this layer negligible. Thus lake levels were effectively constant-head boundaries, as initially assumed. 


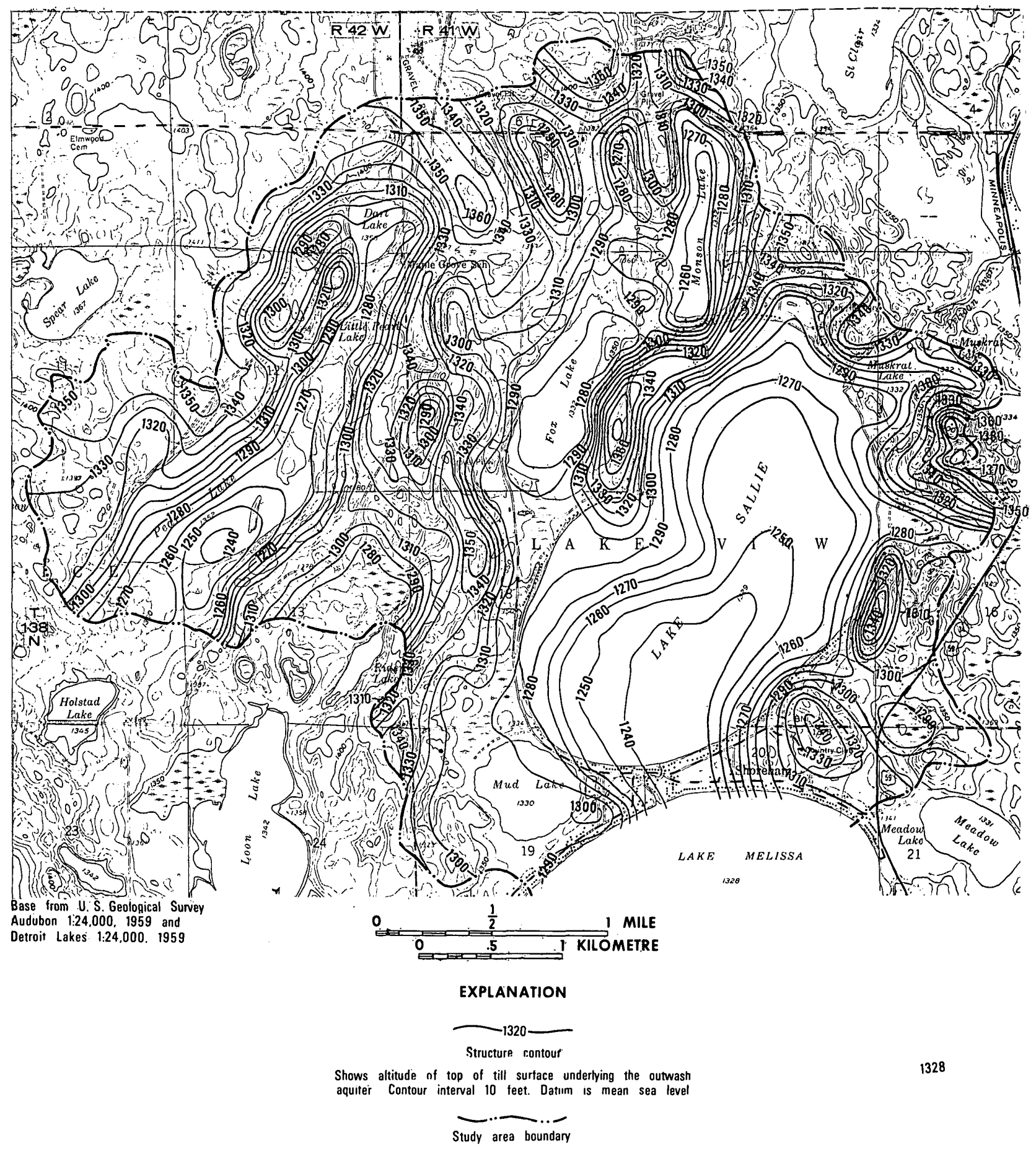

Figure 5.--Configuration of the till surface underlying the outwash aquifer. 


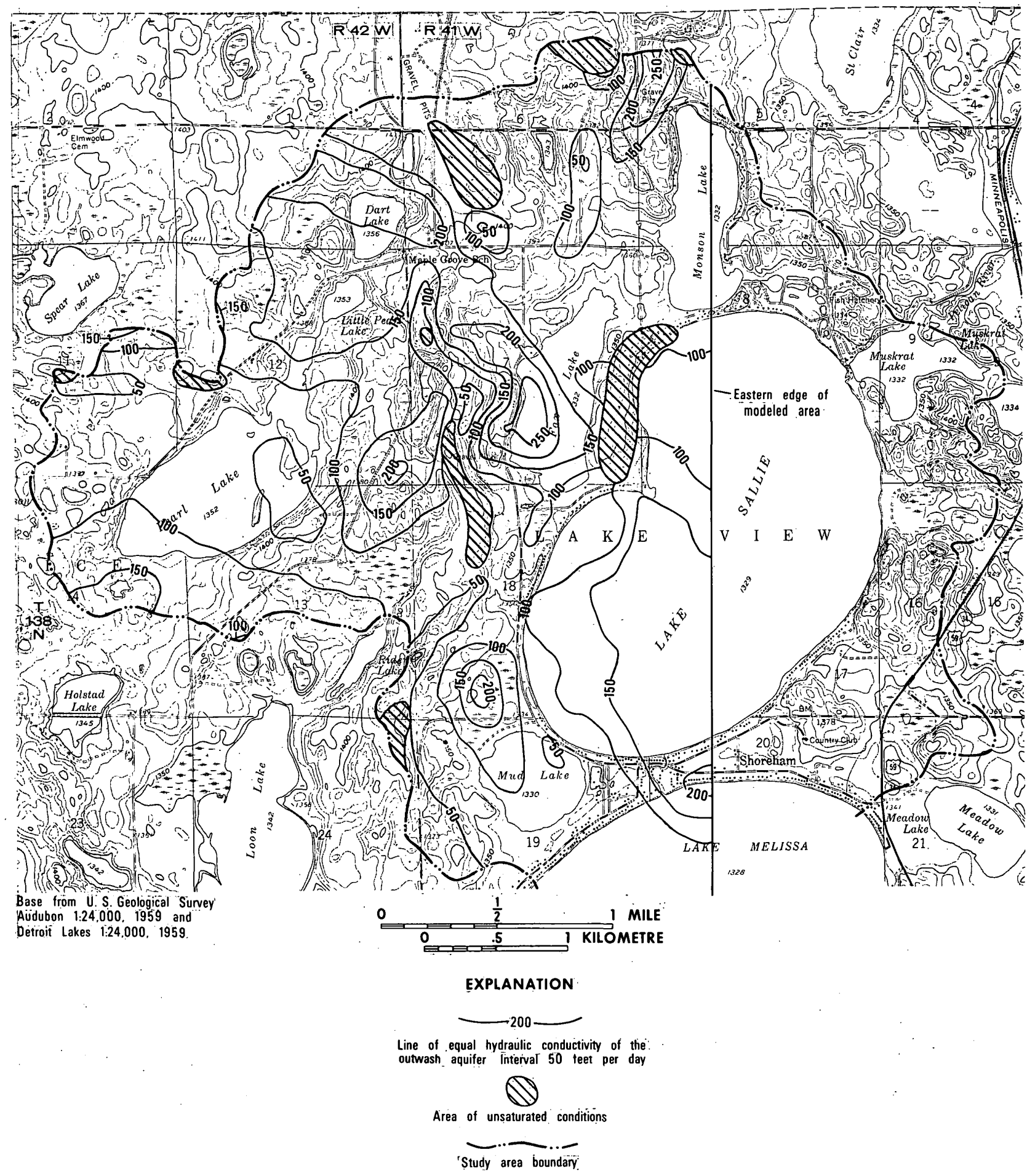

Figure 6.--Hydraulic conductivity of the outwash aquifer. 


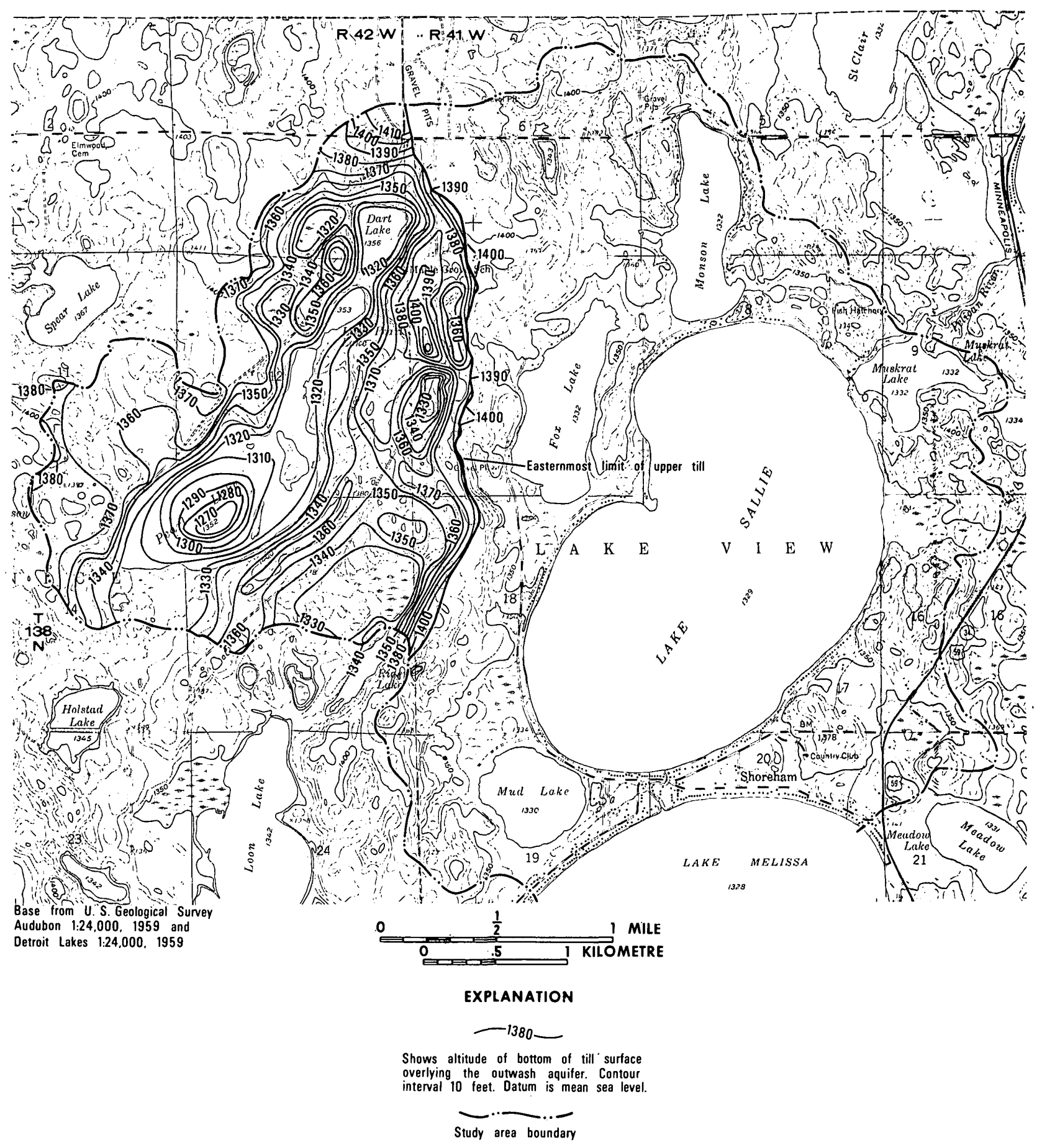

Figure 7.--Configuration of the bottom of the upper till. 


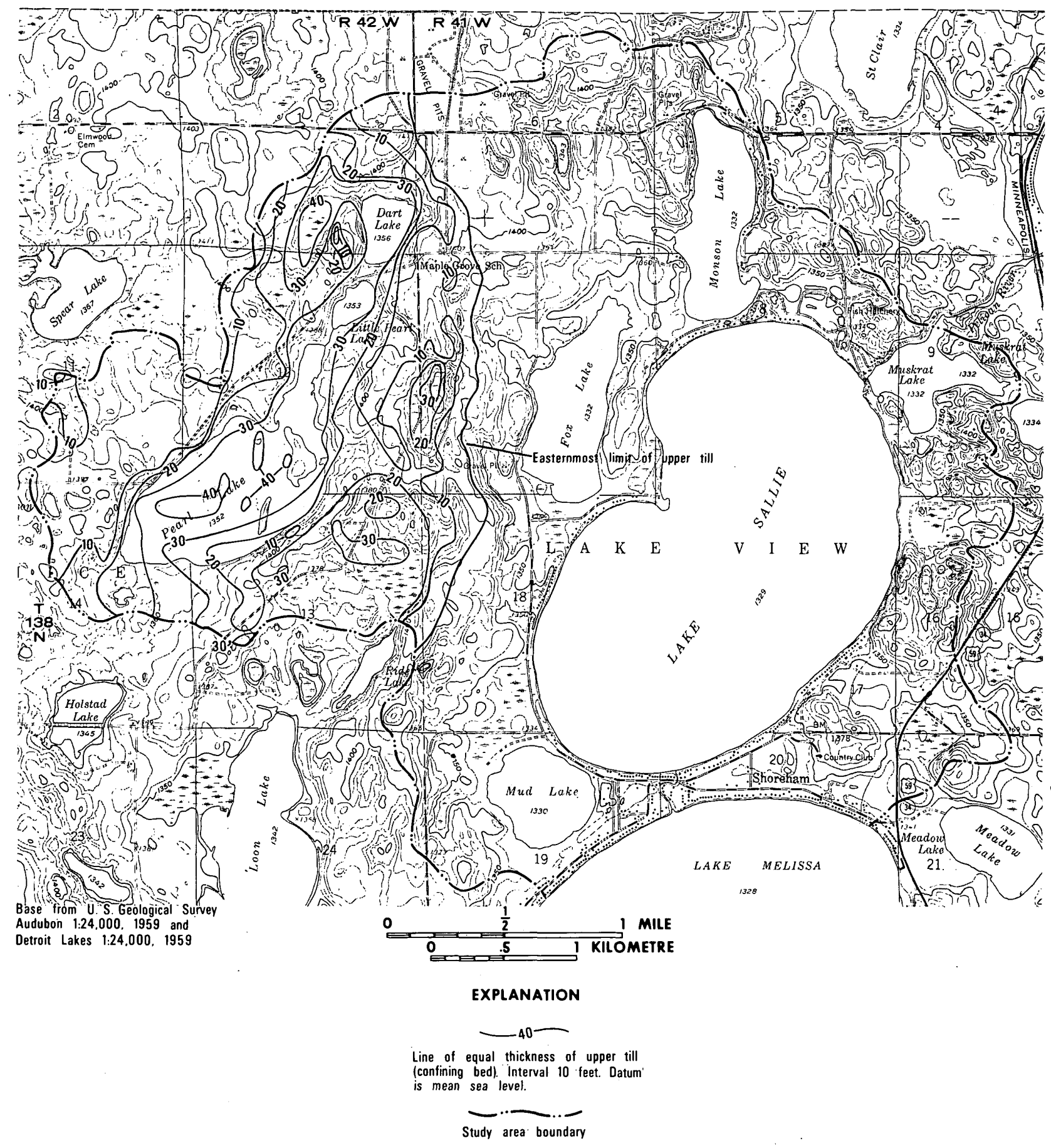

Figure 8.--Thickness of upper tizl. 


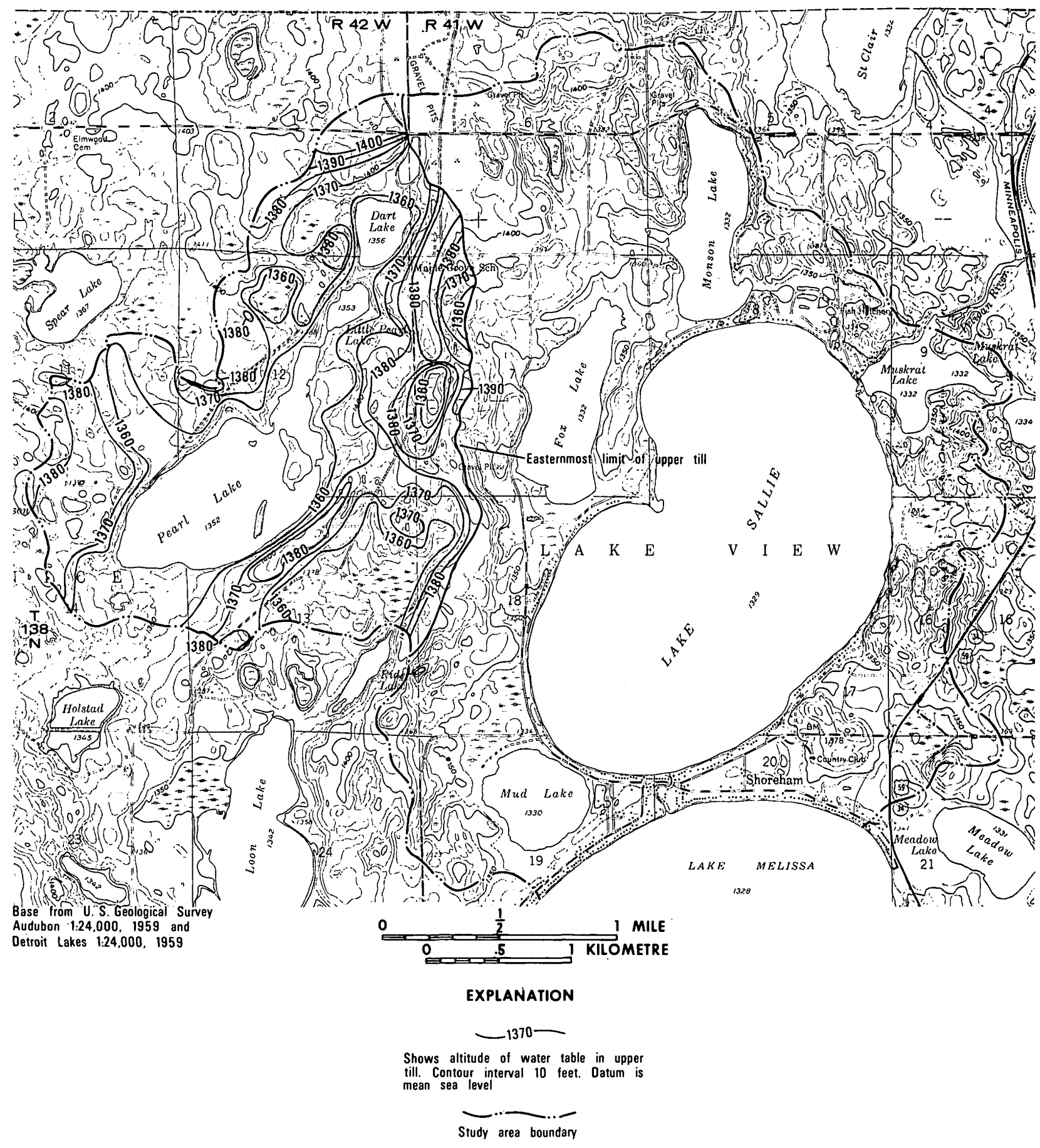

Figure 9.--Configuration of water table in upper tilz. 
Results

Using the model with the boundary conditions outlined above, adjustments were made to the input parameters in an effort to simulate the ground-water flow pattern in the real aquifer satisfactorily and to study the sensitivity of input parameters. The most significant adjustments to the initial interpretations that were needed to obtain reasonable simulations were:

1. extending and modifying the ridge in the aquifer base along the edge of the till area;

2. decreasing the hydraulic conductivity along the ridge, so as to increase hydraulic gradients;

3. including the confining layer beneath lakes in the till area (fig. 1). (Initially, lakes in this area were interpreted as being in contact with the aquifer (penetrating the upper till\}.);

4. reinterpreting the aquifer characteristics beneath lakes in the till area, so as to reflect the existence of the confining layer; and,

5. reinterpreting the observed potentiometric surface considering the effects of (3) and (4) above.

Observed and computed potentiometric surfaces are shown in figures 10 and 1l, respectively. Fluctuation of the observed potentiometric surface was generally less than $1 \mathrm{ft}(0.3 \mathrm{~m})$ except in places affected by the gravel-washing operation. The surface on July 25-26, 1972 (fig. 10), was determined to be an adequate representation of average conditions and was used for comparison with model results. The simulation of this surface by the model was considered satisfactory.

The saturated thickness and transmissivity of the outwash aquifer determined from the computed potentiometric surface (fig. II) are shown in figures 12 and 13. Ground-water flow rates for various components of the aquifer system at the computed equilibrium condition (fig. 1l) are tabulated below in a mass balance format.

Inflow to aquifer

$\begin{array}{rcc} & \underline{\mathrm{ft} / \mathrm{s}} & \underline{\mathrm{m}^{3} / \mathrm{s}} \\ \text { Recharge (outwash area) } & 0.726 & 0.0206 \\ \text { Underflow } & 1.552 & 0.0440 \\ \text { Leakage (till area) } & \underline{1.043} & \underline{0.0295} \\ \text { Total } & 3.321 & 0.0941\end{array}$




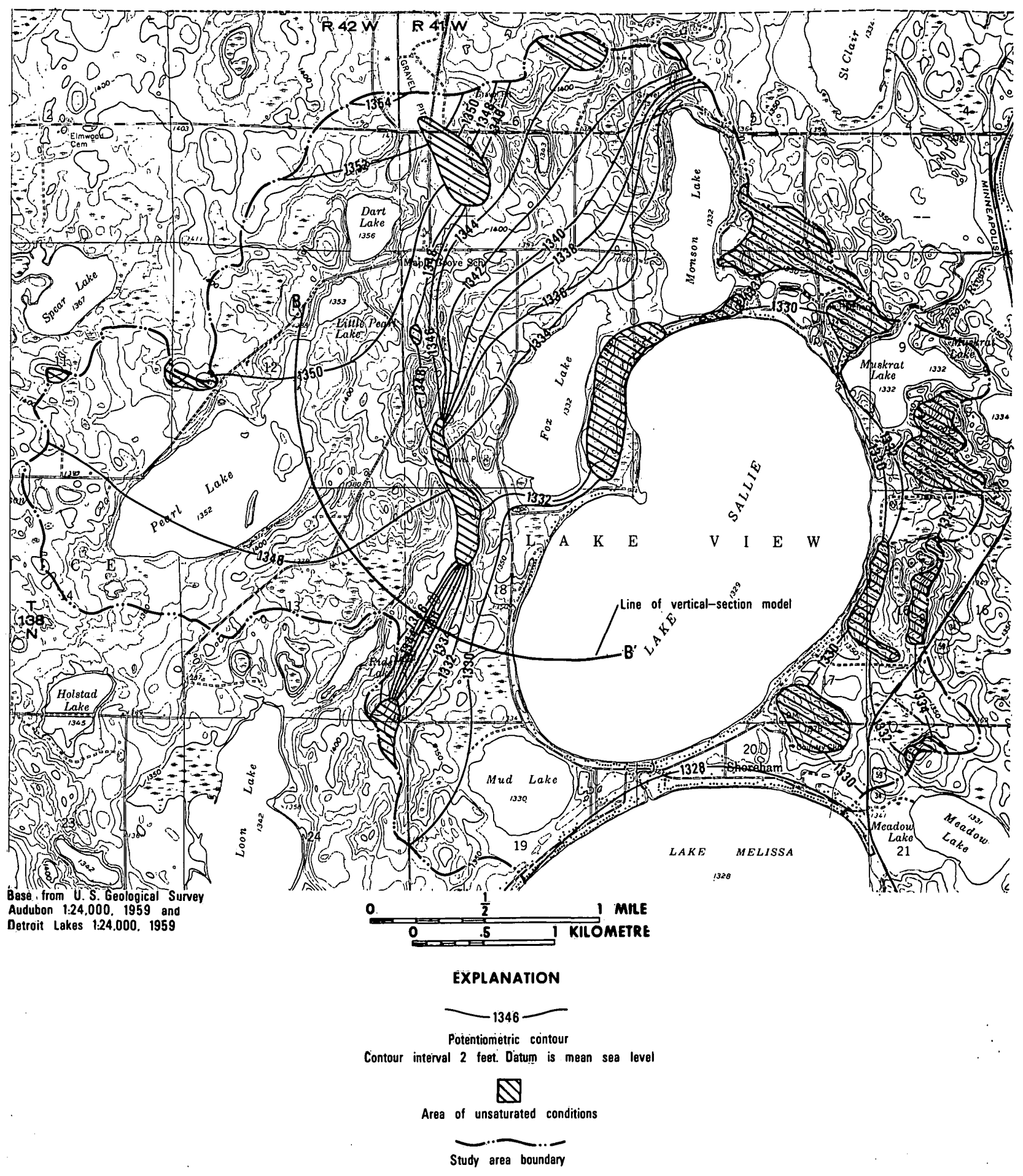

Figure 10.--Potentiometric surface of water in the outwash aquifer, July 25-26, 1972, and line of vertical-section model. 


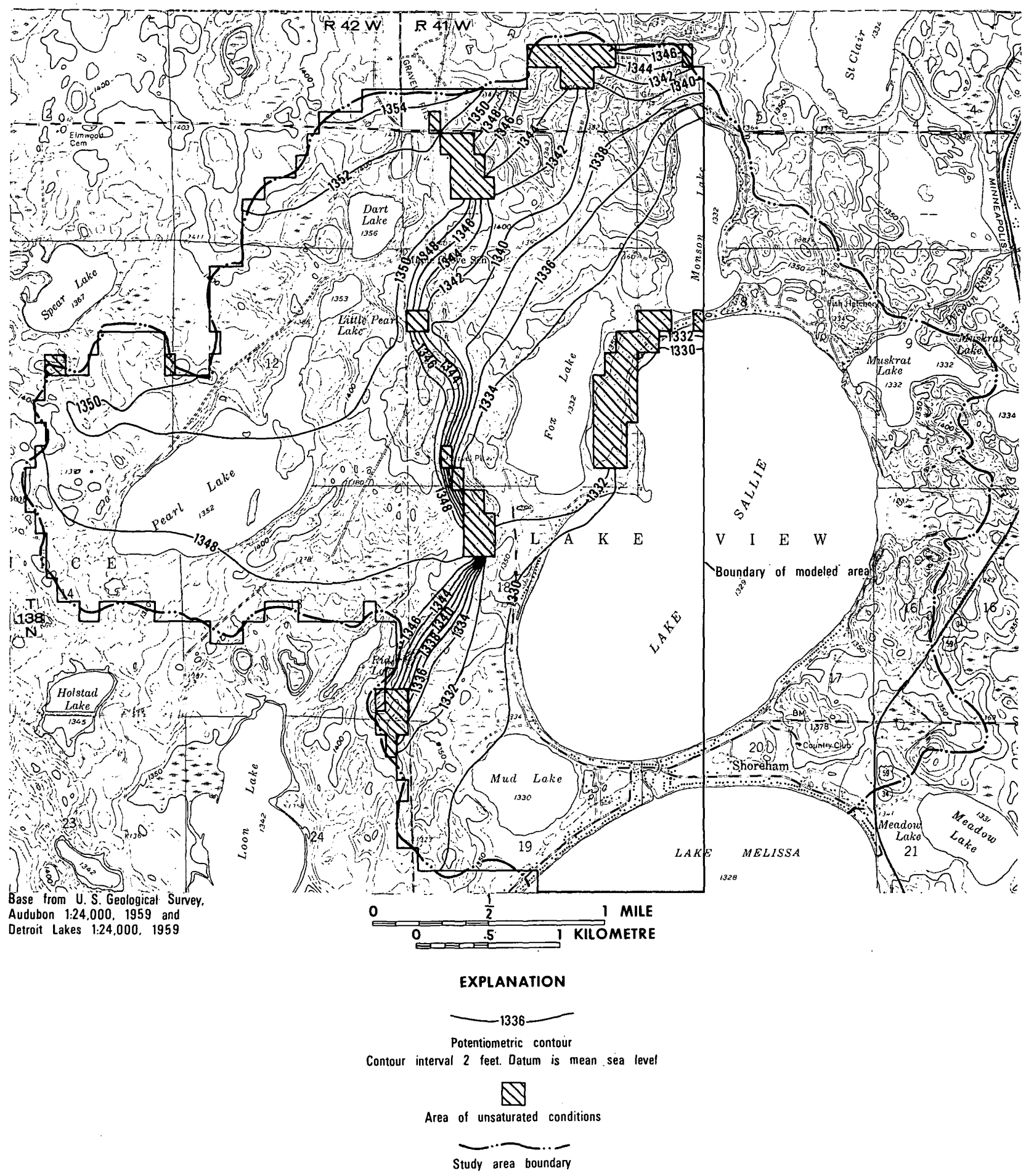

Figure 11.--Steady-state potentiometric surface of water in the outwash aquifer, computed by areal digital model. 


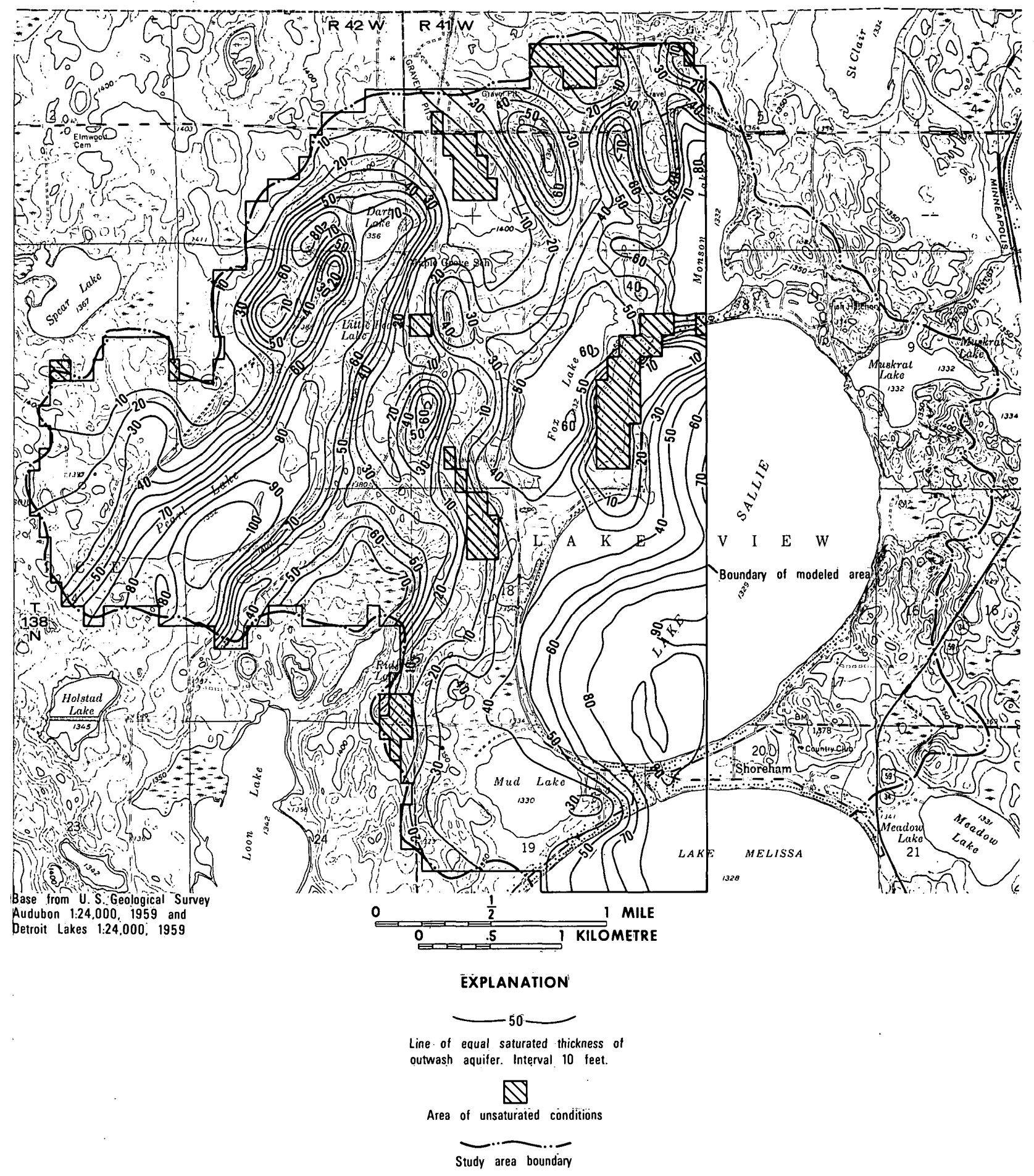

Figure 12.--Computed saturated thickness of the outwash aquifer. 

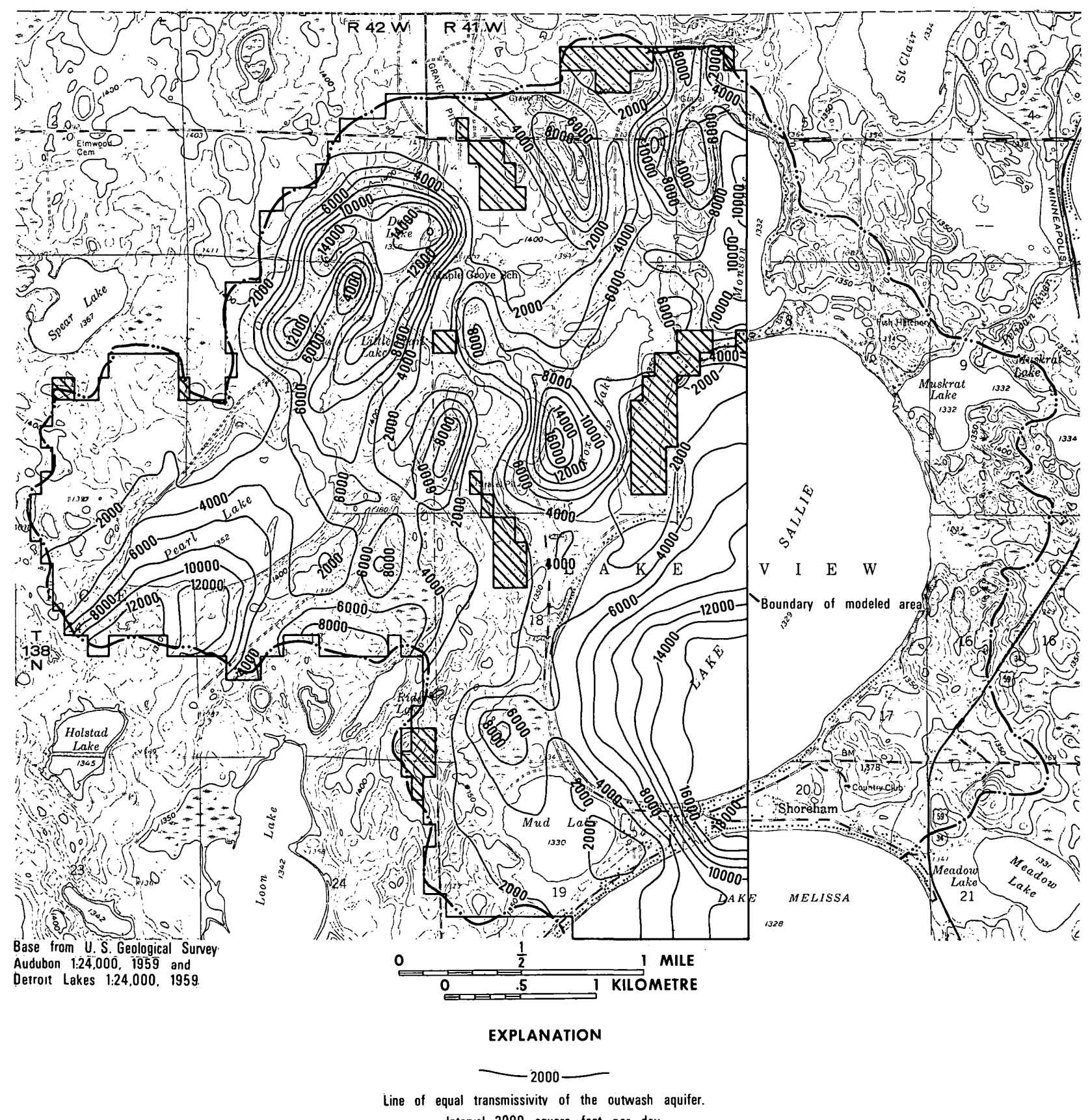

Interval 2000 square feet per day

$\mathbb{\Delta}$

Area of unsaturated conditions

Study area boundary

Figure 13.--Computed transmissivity of the outwash aquifer. 
Outflow from aquifer

$\begin{array}{lcc} & \underline{\mathrm{ft}^{3} / \mathrm{s}} & \underline{\mathrm{m}^{3} / \mathrm{s}} \\ \text { Underflow } & 1.157 & 0.0328 \\ \text { Monson Lake (net flow) } & 0.853 & 0.0242 \\ \text { Fox Lake (net flow) } & 0.515 & 0.0146 \\ \text { Lake Sallie (net flow) } & 0.568 & 0.0161 \\ \text { Mud Lake (net flow) } & 0.057 & 0.0016 \\ \text { Lake Melissa (net flow) } & \underline{0.166} & 0.0047 \\ \quad \text { Total } & 3.316 & 0.0940\end{array}$

The various terms shown in the table all fluctuate with time throughout the year; however, the model treats the problem through a steady-state analysis, and thus computes only a single value for each term, representing the annual average of that term.

Recharge represents the net vertical flow percolating to the water table in the outwash area--that is, in the area in which the aquifer is unconfined. In the model analysis, this recharge was considered to be uniformly distributed over the outwash area, and the value given in the table is the total of this uniformly distributed flow. However, recharge actually represents precipitation minus the sum of evapotranspiration and runoff; in the field, therefore, it must vary both with location and with time. Where the water table is close to land surface, recharge may actually be negative--that is, flow may be directed out of the aquifer, at least during the summer months. In any case, if these point values of recharge are summed algebraically over the outwash area at a given instant, a total net recharge is obtained. The value given in the table represents such a net figure, or more properly, an annual average of net recharge figures calculated in this way.

The leakage term in the mass balance refers to the till area where the aquifer is semi-confined. (See figs. 1 and 4.) As discussed previously, leakage is assumed to be proportional to the head difference between the water table in the overlying till (or lake levels in the till area) and the water level in the aquifer. It is computed for each node in the till area and varies as a function of position. The value presented in the mass balance is a total for the till part of the modeled area, and is the net flow reaching the confined part of the aquifer via vertical movement through the till. It represents precipitation minus the sum of evapotranspiration, runoff, and lateral groundwater discharge from the till to surface-water bodies.

Evapotranspiration is not explicitly included in the mass balance because the recharge and leakage terms represent net additions (or subtractions) to the aquifer after evapotranspiration has been satisfied. 
For each lake, the value indicated represents the net flow across the constant-head boundary that simulates that lake. Interactions with lakes in the till area (Pearl, Little Pearl, and Dart) are included in the leakage term. Underflow represents flow into or out of the aquifer through constant-head nodes at the study area boundary.

All lakes in the outwash area, or at least the parts of them that are simulated, act as ground-water sinks (net outflow) in the aquifer system. However, only Mud Lake and Fox Lake have their entire boundaries within the modeled area ( $f i g .11$ ). Thus a total evaluation of the ground-water-lake interaction can be made only for Fox and Mud Lakes.

The net outflow from the aquifer into Fox Lake as determined from the model is equivalent to about 30 in $(762 \mathrm{~mm})$ per year over the lake surface. Lake evaporation in the study area has been estimated to be about 28 in (71l mm) per year (Meyers, 1962) and residual lake evaporation (evaporation minus precipitation) is about 4.4 in (112 mm) per year. Average surface-water outflow from the lake during water years 1969 and 1970 was estimated to be about 32 in $(813 \mathrm{~mm}$ ) per year per unit area of lake surface. Surface-water inflow consists only of runoff and is estimated to be from 2 to 7 in ( 51 to $178 \mathrm{~mm}$ ) per year. These data indicate that net ground-water flow into the lake should be about 29 to 34 in $(737$ to $864 \mathrm{~mm}$ ) per year, which agrees favorably with model results.

Mud Lake has no surface outflow and receives about 1 to 3 in (25 to $76 \mathrm{~mm}$ ) of runoff annually. Thus, net ground-water flow into the lake should be about 1 to 3 in ( 25 to $76 \mathrm{~mm}$ ) per year. Model results indicate a net inflow of 5.8 in $(147 \mathrm{~mm})$ per year. Considering potential errors in the estimates of lake evaporation and precipitation (see Mann and McEride, 1972), this result is not unreasonable.

Both Fox and Mud Lakes act as "short circuits" for ground water flowing toward Lakes Sallie and Melissa. Model results show that ground water enters Mud Lake along its western shore and is discharged to the aquifer along the eastern shore. Ground water enters Fox Lake along all of its shoreline except at the southern end, where discharge to the aquifer occurs. Most of the ground water that enters Fox Lake flows into Lake Sallie via streamflow. Along the remainder of the lakeshore included in the model (outwash area), ground-water is discharged into lakes except at the southern ends of Monson Lake and Lake Sallie, where water is discharged into the aquifer.

The net flow into Lake Sallie represents about 23 percent of the total net ground-water inflow calculated by Mann and McBride (1972). Although 53 percent of its total lakeshore is included in the model, a significant part of this percentage is adjacent to a till ridge east of Fox Lake (fig. 5) and receives negligible inflow. Thus, lakeshore outside the model area probably receives about 77 percent of the net ground-water inflow into Lake Sallie. 
Leakage rates through the confining layer (till areas) ranged from 0 to 8.7 in $(220 \mathrm{~mm})$ per year per unit area, averaging 5.5 in $(140 \mathrm{~mm})$. This agrees favorably with estimated recharge rates for the study area. (See p. 7.)

The sensitivity of model results to model input parameters can be used to guide the collection of additional field data. The following discussion outlines the effects of various model input parameters that were observed during the simulation of the Pearl-Sallie ground-water flow system. Some components of the ground-water system are a function of more than one input parameter, and therefore input parameters are grouped below, according to the component of the system that they determine:

1. Leakage through confining layer (a function of thickness of the confining layer, hydraulic conductivity of the confining layer, and head above the confining layer)--

Variation of leakage into the aquifer (in the till area) produced significant changes in the computed head distribution. Hydraulic conductivity of the confining layer was the most important input parameter controlling leakage. Variation in head above the confining layer would generally produce compensating changes in the computed thickness of the layer, thus negating its effect on computed results. A value of $2.3 \times 10^{-8} \mathrm{ft} / \mathrm{s}\left(7.0 \times 10^{-9} \mathrm{~m} / \mathrm{s}\right)$ for hydraulic conductivity of the layer produced best results. The only field data on this parameter was the sample of till collected from beneath Pearl Lake ( $p .7)$. Hydraulic conductivity of this sample was determined by laboratory analysis to be $1.25 \times 10^{-9} \mathrm{ft} / \mathrm{s}$ $\left(3.8 \times 10^{-10} \mathrm{~m} / \mathrm{s}\right)$.

2. Transmissivity (a function of aquifer-base altitude, hydraulic conductivity, and altitude of base of upper confining layer)--

Any of the appropriate input parameters could be used to vary transmissivity. However, hydraulic conductivity is generally the most uncertain of these parameters, and changing of its value could be most easily justified. The sensitivity of results to adjustments in transmissivity was varied. In places of increased hydraulic gradient where transmissivity is relatively low, the results were sensitive to adjustments. For example, adjustments were effective along the ridge in the underlying till oriented along the east edge of the surficial till layer (fig. 1). Best results were obtained by decreasing hydraulic conductivity along the ridge to as low as $6.2 \times 10^{-4} \mathrm{ft} / \mathrm{s}\left(1.89 \times 10^{-4} \mathrm{~m} / \mathrm{s}\right)$ for nodes where saturated thickness was modeled to be less than $10 \mathrm{ft}(3 \mathrm{~m})$. In places of relatively greater transmissivity or smaller hydraulic gradient, adjustments had little or no effect on results. 
3. Constant recharge (a specific input parameter)--

Results were generally insensitive to adjustments in uniformly distributed, constant recharge. A rate of $1.2 \times 10^{-8} \mathrm{ft} / \mathrm{s}$ $\left(3.66 \times 10^{-9} \mathrm{~m} / \mathrm{s}\right)$ was introduced for all nodes in the outwash area (fig. 1). However, lakes in this area (constant-head boundaries) were so dominant as controlling factors that variation of the recharge rate produced negligible change in the results.

4. Initial head distribution (a specific set of input parameters)--

Although an initial head distribution was required, the individual head values selected have no effect on the computed results. They serve only as a starting point for the computational procedure.

5. Grid spacing (a specific set of input parameters)--

The effect of using different grid spacings was not investigated. However, the number of nodes chosen $(2,624)$ was considered the minimum necessary for an adequate description of the aquifer properties of the Pearl-Sallie ground-water system. The program required approximately 63 percent of the capacity of a CDC 6600 computer (usable capacity: 36,864 60-bit words).

6. Boundary conditions (specific input parameters)--

Two types of boundary conditions were used in the model-no-flow and constant-head. (See p. 10.) No-flow boundary conditions were selected for all places where the saturated thickness was zero. All remaining boundary nodes not designated as no-flow, as well as all nodes representing lakes in the outwash area, were considered constant-head. Results were sensitive to changes in lake levels because the changes generally had a large area of influence (the entire perimeter of the lake). Changes to boundary constant-head nodes along boundaries of the study area affected only small local areas.

Summary and discussion of areal two-dimensional model

Important characteristics of the areal two-dimensional model are summarized briefly as follows:

1. The effect of areal variation in aquifer characteristics on the flow system can be determined.

2. The effect of external factors, such as lakes, streams, leakage through confining layers, or recharge, can be determined.

3. Vertical movement of water within the aquifer is not considered, but vertical components (leakage or recharge) entering the aquifer must be considered. 
4. Effects on the hydraulic head distribution resulting from pumping or induced recharge of water can be shown. This capability was excluded from the Pearl-Sallie model for computer efficiency but could easily be incorporated if necessary, as could the effects of other transient (nonsteady-state) phenomena.

The model satisfactorily simulated the ground-water flow system in the Pearl-Sallie Lake area. Deviations between computed and observed results can be caused by 1) inaccurate input data, 2) errors inherent in the mathematical formulation and computer calculation, and 3 ) violations of model assumptions, that is, use of a model not suited to the real physical system. Inaccurate input data can be caused by errors in the field data, errors in interpretation and interpolation of field data, and by insufficient collection of field data. Errors inherent in the mathematical formulation and computer calculation are generally small enough to be tolerated. Also, model assumptions must either be accepted or a different model must be used. Thus, given a particular type of model, in order to produce satisfactory simulations, the only recourse is to reduce errors in input data.

Fortunately, the development of a rough generalized model can help to locate potential sources of error. Generalized results will show places where the simulation is inadequate. Adjustments can then be made by rechecking fielc data for possible error, by reinterpretation of the field data, or by collection of additional data. This process can be continued until satisfactory simulations are produced.

Attempts have been made to develop objective methods for determining the relative importance of the various input parameters (Gates, 1971, Meyer, 1971). However, these studies conclude that the worth of input data (or field data) can be evaluated only in reference to a specific area to be modeled. The Pearl-Sallie model contains an excellent example. That is, the most sensitive parameter in the model was the hydraulic conductivity of the confining layer. But this parameter may not even exist in models of some other ground-water flow system. Thus, it is not possible to categorize the importance (or sensitivity) of input parameters on a universal basis. The geometry of the study area, the focus of study, and the acceptable degree of accuracy of results will determine which parameters have greater relative importance.

Vertical-section model

This model simulates steady-state ground-water flow in a twodimensional vertical cross section. Distribution of head within the section is described by the following generalized form of Richards' equation (Richards, 1931): 


$$
\frac{\partial}{\partial x}\left[K x(x, z) \frac{\partial h}{\partial x}\right]+\frac{\partial}{\partial z}\left[K z(x, z) \frac{\partial h}{\partial z}\right]=0
$$

where

$h$ is hydraulic head, (L),

$\mathrm{Kx}(\mathrm{x}, \mathrm{z})$ is hydraulic conductivity in $\mathrm{x}$-direction at point $(\mathrm{x}, \mathrm{z})$, $(\mathrm{L} / \mathrm{T})$, and

$\mathrm{Kz}(\mathrm{x}, \mathrm{z})$ is hydraulic conductivity in $\mathrm{z}$-direction at point $(\mathrm{x}, \mathrm{z})$, $(\mathrm{L} / \mathrm{T})$.

Equation 2 assumes

1. two-dimensional, steady-state ground-water flow,

2. nonhomogeneous, anisotropic medium, and

3. principal axes of hydraulic conductivity alined with coordinate axes.

This equation and specified boundary conditions constitute the basis for a mathematical model of a ground-water flow system. The model computes an approximate solution in a manner similar to that of the areal model. A finite-difference equation, derived from equation 2 , is applied to each nodal point of a grid covering the cross section. This results in a set of simultaneous linear equations, in as many unknowns as there are nodes in the grid. The equations are solved by the point successive over-relaxation method (PSOR) as described by Freeze and Witherspoon (1966) and in various texts on numerical solution of partial differential equations (for example, von Rosenberg, 1969; Mitchell, 1969). The solution consists of a set of head values, one value for each node.

Because subsurface materials are commonly layered, a simplification is introduced to speed data input and reduce computer storage. The model is made to represent a vertical section consisting of a series of layers. Layers need not extend across the entire section. Each is modeled as internally homogeneous; thus only a single horizontal and vertical hydraulic conductivity need be specified for a layer.

Model inputs

Input to the model includes the following:

1. geometry of the various layers within the section,

2. directional (horizontal and vertical) hydraulic conductivities for each layer,

3. configuration of the water table or the distribution of potential along the upper boundary of the modeled section, 
4. boundary conditions on the left and right ends and along the bottom of the section, and

5. initial head at each node within the section.

A no-flow (impermeable) boundary or a constant-head boundary can be selected along the bottom of the modeled section. The right and left end boundaries are taken to be vertical and may be constant-head or impermeable. The upper boundary is assumed to be constant head and is located along the top of the modeled section.

\section{Model output}

Output from the model includes a plot showing distribution of head within the section. Comparison of calculated heads with those measured in the field can be used to guide adjustment and refinement of the hydrogeologic interpretation based on field data. This process allows for a better interpretation of the hydrogeology than could be derived without aid of the model.

Flow lines can be derived from the head (potential) distribution. They cross equipotential lines at angles which depend on the degree of anisotropy of the permeable materials and on the vertical exaggeration used in representing the section. Flow lines indicate the positions of recharge and discharge areas and show roughly the paths taken by contaminants in the ground-water system. Used together with equipotential lines, they allow for calculations to estimate recharge and discharge rates at the lake-ground-water interface, the volumetric flow rate of ground water, and the transport velocity of contaminants in solution.

\section{Application of the vertical section model}

The section chosen for modeling follows a flow line (as seen in map view) in a curved path from north of Pearl Lake to the southwest shore of Lake Sallie. (See fig. 10.) The total length of the section was $12,000 \mathrm{ft}(3,660 \mathrm{~m})$, extending $2,000 \mathrm{ft}(610 \mathrm{~m})$ out into Lake Sallie. Total depth of the section was $130 \mathrm{ft}(40 \mathrm{~m})$. A grid of 121 nodes in the horizontal direction by 27 nodes in the vertical direction was used, resulting in nodal spacing of $5 \mathrm{ft}(1.5 \mathrm{~m})$ vertically and $100 \mathrm{ft}(30 \mathrm{~m})$ horizontally. On a CDC 6600 computer, the model required a minimum of $36,700_{8}$ (octal) words of storage to load and execute and used approximately 0.07 seconds of central-processor time per iteration.

Figure 14A illustrates the geology along the section, and figure 14B the head distribution inferred from field evidence. Two layers were chosen to comprise the model, the lower representing saturated outwash and the upper representing saturated till and lake sediments. Their hydraulic conductivities are given in table 1 . The water table 

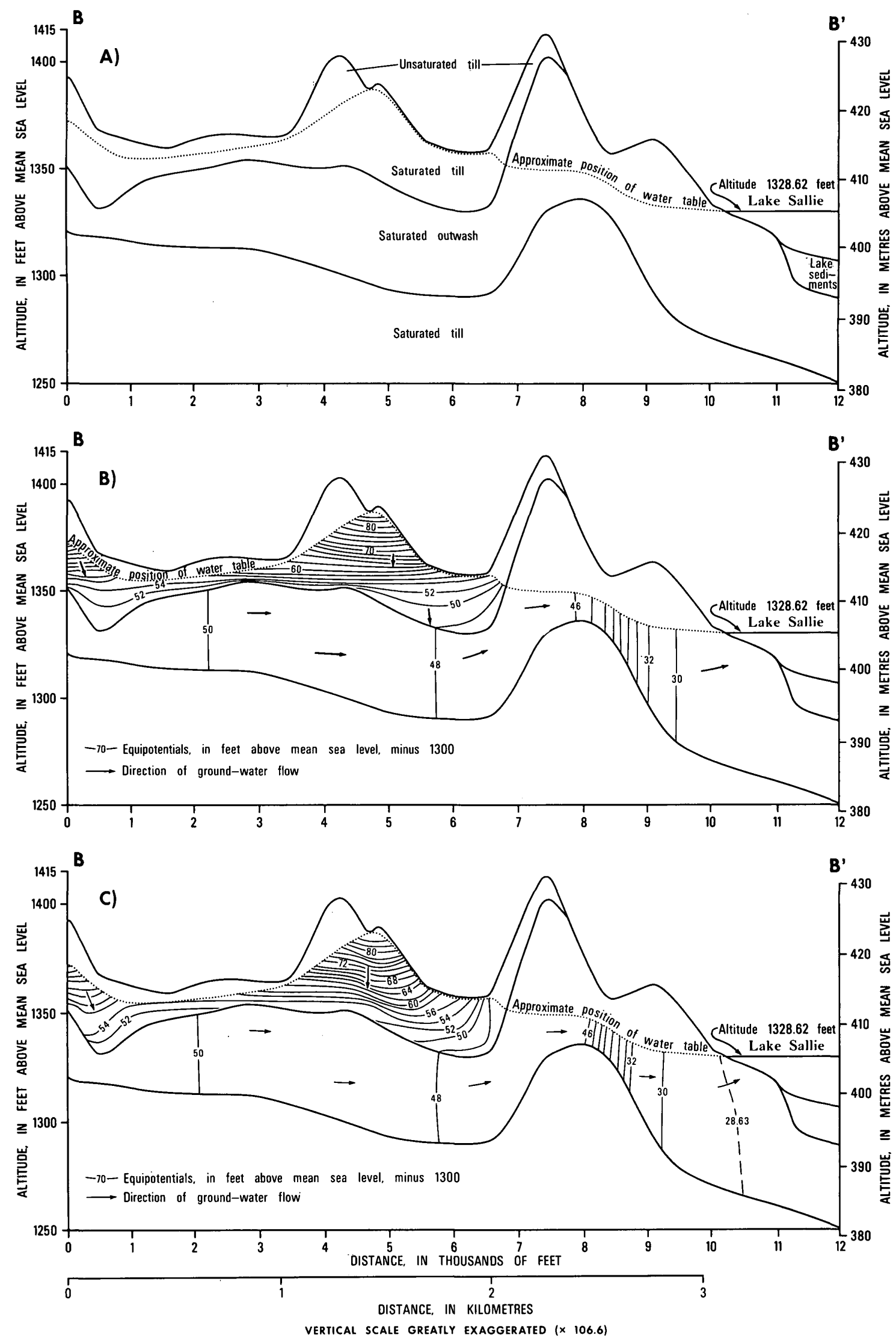

Figure 14.--Hydrogeology and vertical-section model results in PearlSallie Lakes area, Minnesota. A) Hydrogeologic section, B) potential distribution as inferred from field data, and C) potential distribution as calculated by moder. (Line of section shown on fig. 10.) 
constitutes the upper boundary and is simulated by using constanthead nodes. Till below the outwash was represented by a no-flow boundary. Vertical constant-head boundaries were used at the left and right sides of the section. Lake Sallie, bottomed in outwash, was simulated by applying a constant head equal to lake level along the lake bottom. Lakes bottomed in till could be simulated in the same way, although none occur in this section.

\begin{tabular}{lcccc}
\hline & Horizontal & \multicolumn{2}{c}{ Vertical } \\
& $\mathrm{ft} / \mathrm{d}$ & $\mathrm{m} / \mathrm{d}$ & $\mathrm{ft} / \mathrm{d}$ & $\mathrm{m} / \mathrm{d}$ \\
\hline Till & 0.00032 & 0.000098 & 0.00032 & 0.000098 \\
Outwash & 320 & 98 & 32 & 9.8 \\
\hline
\end{tabular}

Table 1.--Values of hydraulic conductivity estimated from field data and used in vertical-section model.

In figure 14 the vertical scale has been exaggerated about 570 times, causing a distortion in the shape of the equipotential lines and in the indicated directions of flow.

\section{Results}

Results from the model are shown in figure 14C. The head distribution is close to that estimated from field evidence. Equipotential lines in the till are generally horizontal, those in the outwash vertical. Thus flow is vertical in the till and horizontal in the outwash.

It is not possible to compare the model results with detailed field results, as was done with the areal model, owing to lack of data. Only three observation wells lie in the line of section. No other wells are less than $1,000 \mathrm{ft}(305 \mathrm{~m})$ from the line of section.

An indirect check on the validity of the model may be made by examining vertical components of flow near the edge of the lake. The $28.63-\mathrm{ft}(8.726-\mathrm{m})$ equipotential of figure $14 \mathrm{C}\left(0.01 \mathrm{ft}\left\{3.0 \times 10^{-3} \mathrm{~m}\right\}\right.$ above lake level) is curved, indicating significant flow upward to the lake. This emerges as seepage through the lake bottom. 
A quantitative measure of the magnitude of vertical flow components is the relation between seepage rate and distance from shore. This may be determined with the aid of figure 15, which shows the horizontal flow rate within the outwash as a function of distance from the lake shore, measured out into the lake. The units of flow, $\mathrm{\mu m}^{3} / \mathrm{s}$ (cubic micrometers per second), are based on assuming a width of the section, in a direction into the page, of $1 \mu \mathrm{m}$. The horizontal flow is calculated by applying Darcy's Law between adjacent columns of head values calculated by the model. The flow rate decreases approximately exponentially with distance from shore.

Losses from ground-water flow that cause the decrease in horizontal flow rate can occur only through the lake bottom. Therefore, the rate of change of horizontal flux can be identified with the rate of seepage. On a semilogarithmic grid the rate of change of a straight-line function, expressed as a function of the same independent variable, is also a straight line having the same slope as the original function. This means that the rate of seepage into the lake is highest at the shore line and decreases exponentially with distance from shore.

Figure 15 shows the decrease in the rate of horizontal flow and of seepage as one order of magnitude for every $270 \mathrm{ft}(82 \mathrm{~m})$. Lee (1972) made extensive field measurements of the rate of seepage into Lake Sallie near the line of cross section. These data suggest an actual decrease of one order of magnitude in $200 \mathrm{ft}(60 \mathrm{~m})$. The agreement between these figures is satisfactory, considering the many approximations involved in the model.

Results indicate that the concentration of seepage near lake shores and the exponential decrease in seepage rates with distance from shore seem likely in most lakes and are not particularly sensitive to the presence or absence of fine-grained lake-bottom sediments. System boundary conditions (lake level) seem to be the most important factor in determining the flow pattern. These effects are described in greater detail by McBride and Pfannkuch (1975).

Shortcomings and difficulties

Problems involved in the construction and use of the verticalsection model used in this study include 1) exclusion of flow in the unsaturated zone, 2) limitations in the computer program, 3) slow convergence of the model to a solution, 4) difficulty in acquisition of input data, and 5) uncertainty of true field conditions. These are discussed, in order, as follows.

Because the water table is used as the upper limit, the model neglects flow in the unsaturated zone and, thus, is incapable of modeling movement of water in a part of the subsurface. Other verticalsection models could be made to deal with unsaturated flow, but they are much more complex than this model and require more elaborate input data. 


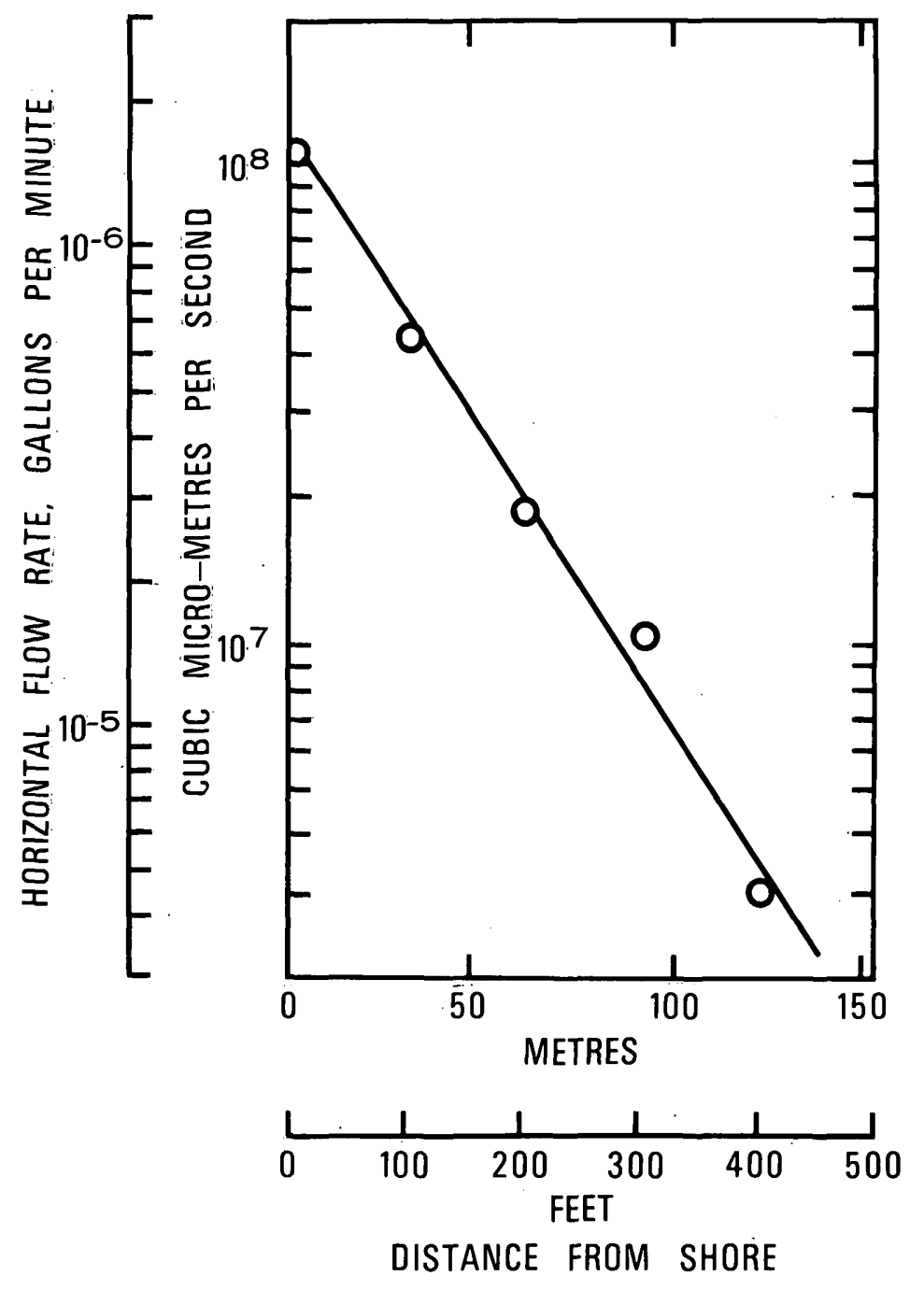

Figure 15.--Horizontal ground-water flow rate as a function of distance from shore, as predicted by vertical-section model. 
Certain limitations are peculiar to the program used in this model. For example, assumptions of layered materials having the same permeability in each layer make it difficult to simulate flow where the geology is complex, on where conductivity values change gradually. Also, where conductivity contrasts are large, the model's convergence to a solution can be extremely slow. However, the method (PSOR) used for solution is stable even for conductivity contrasts as large as 1 million to 1 . Complex sections could be better modeled by assigning a separate horizontal and vertical conductivity to each node within the finite-difference grid, rather than by layers. In doing this, the program change would be minor, but the labor of coding would increase. Speed in convergence might be gained by using a different numerical method for solution, but, then, limitations might be put on the situations that could be modeled.

Great difficulty was experienced in producing a solution within an acceptable amount of computing time. The causes are not precisely known, but several generalizations can be made to aid future modeling efforts. First, it is vital in modeling complex sections that the initial heads input to the model be reasonably close to the final results. Early runs of the Lake Sallie model set initial head in each column of nodes to the head at the water table in that column. Although this scheme proved satisfactory for single-layer models, the initial head in the outwash was set too high in columns where the water table in the till was high. With these starting heads, the model was still far from a solution after 16,000 iterations, requiring 1,121 seconds of computer time. A data set of starting heads determined from figure 14B gave better results. Best results were obtained by modeling till and outwash as two separate systems using equivalent conditions along the common boundary. The computed heads for each system were then used as starting heads in the original model. Second, it is often easy to detach part of a section and model it separately. The part of the outwash not covered by till was modeled in this manner using a vertical equipotential just to the right of the edge of the till as the left boundary. Solution was reached in only 18 iterations. The result was practically identical to that from the corresponding part of figure $14 \mathrm{C}$. Thus, if only the part of the section close to the lake were of interest, much difficulty could be avoided by restricting modeling efforts to that part.

Input data are more difficult to obtain for a vertical-section model than for an areal model. Observed data can be extrapolated for much greater distances horizontally than vertically because geologic materials are commonly deposited in layers. Seldom are variations in physical parameters accurately determined in the vertical direction because of the difficulty and costs involved in obtaining such information. 
True field conditions in the vertical section are uncertain. Data collection in the Lake Sallie area was largely oriented toward obtaining horizontal flow patterns in the outwash, not toward definition of flow along any particular flow path. Data taken from areal maps were necessarily generalized by being interpolated from points off the section. The position of the water table in the till is approximate, being based on only one observation well in the till and on the occurrence of marshy areas and small ponds. Marshy areas and small ponds were considered to be surficial expressions of the water table in the till area. The configuration of the bottom of the uppermost till is similarly uncertain.

\section{Summary and discussion of vertical cross-section model}

The program presented here is capable of modeling many situations of interest in the study of the relations between ground water and lakes.

Particular advantages of the program include simple and rapid setup of data; small machine storage requirements; ability to deal successfully with extreme inter-layer conductivity contrasts; and, in favorable cases, rapid solutions.

Like all modeling programs, this one has defects. It cannot model sections in which the hydrogeology is complex. Certain cases that can be modeled cannot be solved economically. Transient conditions or unsaturated flow cannot be represented.

These problems could be met by using other mathematical techniques. Other techniques, however, will have other deficiencies. The technique to be used for representing any particular vertical section will have to depend on the hydrogeology of the section, the needs of the project, and the availability of data.

The model described here probably has its greatest value in theoretical studies of lake-ground-water relations. The simplicity and speed of data input make it attractive for quick testing of the physical validity of conceptual models of these relations. It would probably be worthwhile to develop other models, using other methods of solution and having greater capabilities for routine modeling of real lakes. 
The surficial outwash aquifer in the Pearl-Sallie Lakes area ranges from 0 to $100 \mathrm{ft}(0$ to $30 \mathrm{~m})$ in thickness and dominates the local ground-water flow system. It crops out in the eastern part of the area and is sandwiched between two beds of till in the western part. Lakes in the western part (Pearl, Little Pearl, and Dart Lakes) are separated from the aquifer by clay till, whereas those in the eastern part (Mellissa, Mud, Sallie, Fox and Monson Lakes) are in the outwash. Water entering the ground-water system moves generally horizontally through the aquifer and is discharged into the lakes in the outwash area.

Digital models were developed to simulate flow in the aquifer, and results indicated that the lakes play an important part in determining flow characteristics in the aquifer. Results from the areal. model show that lakes in the outwash area control the head in the aquifer near the lake shore because the lake levels are controlled by surface-water inflow and outflow. Vertical-section model results indicate that discharge from the aquifer into the lakes is concentrated near the shore.

The two models can not be compared, strictly, as vertical groundwater flow is distinctly different from horizontal ground-water flow. This difference determines the applicability of either model to a particular ground-water flow problem. Computationally, the models are similar. That is, both are used to solve a set of simultaneous equations, and, with modifications, either model could potentially be used to simulate either facet of the system (areal or vertical). However, the mathematical techniques of solution (IADI versus PSOR) have individual advantages and disadvantages, which determine the usefulness of each model.

Data required to use either model are essentially fixed by the characteristics of the model (p. 10 and p. 28); that is, specific input data must be provided to each computer program. Field data collected in the Pearl-Sallie Lakes area were oriented more toward areal modeling. Thus, more estimates and assumptions were needed to provide the necessary input for the vertical-section model than for the areal model. However, quality of the input data (measured, interpreted, or estimated) may or may not appreciably affect results, depending upon 1) the significance of the particular data element to the ground-water flow system and 2) the acceptable accuracy of results. For example, if the semiquantitative results obtained from the vertical-section model were acceptable, the estimates and assumptions used would be justified. If results were not acceptable, more extensive data collection would be required. 
The following conclusions resulted from the digital-model development in the Pearl-Sallie area.

1. Satisfactory calibration of both models with "observed" conditions was obtained.

2. The assumptions used to simulate the effects of lakes on the ground-water flow system were reasonable.

3. Models provide potential means of evaluating the worth of additional field data collection with respect to the need for a more complete understanding of the hydrogeologic system.

4. Field data were not generally available for the verticalsection model, and much more estimation was required than for the areal model.

5. Problems encountered with the vertical-section model indicate that some systems may be very difficult to model.

6. The process of developing digital models led to a more complete understanding of the hydrogeologic system in the Pearl-Sallie lakes area.

Areal and vertical-section models were used to simulate and to study the lake-ground-water flow system in the Pearl-Sallie Lakes area. Steady-state flow rates, recharge or discharge, can be calculated using model results (potential distributions) and basic ground-water-flow equations. With appropriate modification, the models could be used to predict aquifer response to transient stresses. They could also be incorporated into more complex models to determine the movement of solutes in the ground-water system, which, in turn, could aid in the study of lake-eutrophication problems. The application of digital models to study the ground-water flow system in the Pearl-Sallie lakes area demonstrates their value as tools for interpreting system characteristics and for providing quantitative results. 


\section{REFERENCES}

Fenneman, N. M., 1938, Physiography of eastern United States: New York, McGraw-Hill, 714 p.

Freeze, R. A., and Witherspoon, P. A., 1966, Theoretical analysis of regional ground-water flow: 1 . analytical and numerical solutions to the mathematical model: Water Resources Res., v. 2, no. 4, p. 641-656.

Gates, J. S., 1971, Worth of data used in digital-computer models of ground-water basins: Tech. Repts. on Hydrol. and Water Resources, Tech. Rept. 8, University of Arizona, 214 p.

Lee, D. R., 1972, Septic tank nutrients in groundwater entering Lake Sallie, Minnesota: M.S. Thesis (unpublished), Grand Forks, North Dakota University, $96 \mathrm{p}$.

Mann, William B., IV, and McBride, Mark S., 1972, The hydrologic balance of Lake Sallie, Becker County, Minnesota: U.S. Geol. Survey Prof. Paper 800-D, p. D189-191.

McBride, M. S., and Pfannkuch, H. 0., 1975, The distribution of seepage within lakes: U.S. Geol. Survey Jour. Research, v. 3, p. 505-512.

Meyer, C. F., 1971, Using experimental models to guide data gathering: Jour. Hydraulics Div., Am. Soc. Civil Engineers, v. 97, HY10, p. 1681-1697.

Meyers, J. S., 1962, Evaporation from the 17 Western States: U.S. Geol. Survey Prof. Paper 272-D, p. 71-100, pl. 3.

Mitchell, A. R., 1969, Computational methods in partial differential equations: New York, John Wiley, 255 p.

Pinder, G. F., 1970, A digital model for aquifer evaluation: U.S. Geol. Survey Tech. Water-Resources Inv., book 7, chap. C-1, 18 p.

Pinder, G. F., and Bredehoeft, J. D., 1968, Application of the digital computer for aquifer evaluation: Water Resources Research, v. 4, no. 5, p. 1069-1093.

Prickett, T. A., and Lonnquist, C. G., 1971, Selected digital computer techniques for ground-water resource evaluation: Illinois State Water Survey Bull. 55, 62 p.

Reeder, H. 0., 1972, Availability of ground water for irrigation from glacial outwash in the Perham area, Otter Tail County, Minnesota: U.S. Geol. Survey Water-Supply Paper 2003, 45 p. 


\section{REFERENCES--Continued}

Richards, L. A., 1931, Capillary conduction of liquids through porous mediums: Physics, v. 1, p. 318-333.

Stephenson, D. A., 1971, Ground-water flow system analysis in lake environments, with management and planning implications: Water Resources Bull., v. 7, no. 5, p. 1038-1047.

Von Rosenberg, Dale U., 1969, Methods for the numerical solution of partial differential equations: New York, American Elsevier, $128 \mathrm{p}$.

Winter, T. C., Bidwell, L. E., and Maclay, R. W., 1969, Water resources of the Otter Tail River watershed, west-central Minnesota: U.S. Geol. Survey Hydrol. Inv. Atlas, HA-296.

Wright, H. E., Jr., and Ruhe, R. V., 1965, Glaciation of Minnesota and Iowa in Wright, H. E., Jr., and Frey, D. G. (Eds.), The Quaternary of the United States: Princeton University Press, Princeton, New Jersey, p. 29-4l. 